\title{
Monitoring and Market Power in Credit Markets
}

\author{
Ari Hyytinen* \\ Bank of Finland and Helsinki School of Economics and Business Adminisration \\ and \\ Otto Toivanen \\ Helsinki School of Economics and Business Administration
}

this version December 1999

\begin{abstract}
We study an oligopoly model of banking that allows us to evaluate the two leading explanations for banks' ability to earn rents. In the model, banks can either invest in information acquisition, or in market power (through product differentiation). The two versions generate different predictions that are tested using panel data on Finnish local banks. We find that banks' investments in branch network density and human capital (personnel) contribute to the information acquisition ability of banks as both loan interest rates and default costs are decreasing in these variables. We also find that managing customers' money transactions enables banks to better control risks in their lending.
\end{abstract}

JEL: D21, G21, L15

Keywords: banks, information acquisition, market power, sunk costs, branch network, default costs

Addresses: Ari Hyytinen, Financial Markets Department, Bank of Finland, P.O. Box 160, 00101 Helsinki, Finland, Email: Ari.Hyytinen@bof.fi, Tel. +358 9 1832111.

Otto Toivanen, Economics Department, Helsinki School of Economics, P.O. Box 1210, 00101 Helsinki, Finland. Email: toivanen@hkkk.fi, Tel. 358943138663.

\footnotetext{
* The views expressed here are those of the authors and do not necessarily reflect the opinions of the Bank of Finland. We would like to thank the Research Foundation of Finnish Cooperative Banks for providing us with the bank data. Seminar participants at MIT IO lunch, Lappeenranta, Helsinki and the North American Summer Meeting of the Econometric Society provided valuable comments, as did Pekka Ilmakunnas, Heikki Koskenkylä, Peter Rousseau, Petri Rouvinen and Xavier Vives. We would also like to thank Antti Kuusterä and Harriet Uusi-Äijö for providing us with essential background information on cooperative banks. The second author would like to thank both the Research Foundation of Finnish Cooperative Banks and the Yrjö Jahnsson Foundation for financial support, as well as MIT and NBER for hospitality during this project. The usual caveat applies.
} 



\section{$1 \quad$ Introduction}

There exists plenty of empirical evidence that banks do earn rents (e.g. Fama, 1985, Cosimano and McDonald, 1998, Molyneux et al., 1994; and the wave of recent bank mergers). In this paper we will contrast, within a unified modeling framework, the two main theoretical explanations put forth in the literature, and test their empirical validity.

A stream of literature (e.g. Leland and Pyle, 1977, Fama, 1985, Broecker, 1990, Sharpe, 1990) suggests that banks' raison d'etre is to collect and analyze information, or information acquisition as we will call it. Banks could for example, as in Broecker's model, test customers for their creditworthiness in order to avoid adverse selection. Such actions (learning the customer's type) gives a bank bargaining power that it can translate into a larger share of the surplus. An equally old and plentiful (e.g. Klein, 1971, Degryse, 1996) literature argues that banks' source of rents stems from industrial organization-type sources of an oligopolistically small number of firms, product differentiation, and/or price discrimination (that is not based on customer risk characteristics). ${ }^{1}$ These sources of rents we will henceforth call market power. As far as we know, only the latter of these two explanations has been tested empirically (e.g. Spiller and Favaro, 1984). ${ }^{2}$

Whether banks are engaged in one or the other activity may have large consequences outside the industry itself: a large literature suggests that banks' (in)ability to solve informational problems affects the severity of the effects of macro-level shocks (e.g. Greenwald and Stiglitz, 1993, Holmstrom and Tirole,

\footnotetext{
${ }^{1}$ See Freixas and Rochet (1997) for a comprehensive treatment of both literatures.

2 There is of course an enormous empirical literature on banking. To the best of our knowledge, however, these papers are not concerned with the questions studied here. A paper by Petersen and Rajan (1994) comes close in that they study the effects of long-term relationship on terms of credit.
} 
1997). It is therefore of first rate importance to know whether, and through which mechanisms banks collect and process information. There exists indirect evidence that banks are indeed acquiring information (Petersen and Rajan, 1994, James, 1987, Toivanen and Cressy, 1998, Mester et al., 1998), but little or no direct evidence. $^{3}$ The main objective of this paper is to provide the first direct test of (the means of) information acquisition in banking.

A common feature of information acquisition and market power is that they both most likely necessitate sunk investments (but see Petersen and Rajan, 1994, and Section 4). Notwithstanding recent investments in electronic banking, the most obvious such investments of commercial banks are their branch network, and the human capital of their employees. We argue that branches and human capital can serve two purposes. They can either be investments in information acquisition, (and/) or investments in market power. Acquiring information necessitates personnel who can collect and analyze it, and investments in human capital increase the capability of a bank's personnel to deal with these tasks. Information is often local, and therefore a local presence (in the form of a branch) may facilitate the collection of such information. ${ }^{4}$ But equally plausibly, one could argue that a large branch network enables the bank, through either horizontal (providing services close by to a larger clientele) or vertical (by providing a denser network of services to a given customer) product differentiation, to increase its price-cost margins. Likewise, a better-trained and educated workforce may lead to a higher

\footnotetext{
3 Petersen and Rajan find that firms with longer bank relationships have better access to credit. James finds that the stock market reacts favorably to news about new bank loans. Toivanen and Cressy cannot reject the Null of symmetric information when testing the determinants of loan contracts, and attribute this to bank information acquisition. Mester, independently from us, finds that checking accounts provide banks with information about the riskiness of loans.

${ }^{4}$ We've been told that in the 70's and 80's, a Finnish bank's policy was that its local managers have to become members of either the local Lion's, or Rotary's. Although this can partially be explained by them being able to attract business in this way, an alternative explanation is that they were thus in a position to better gather local information.
} 
(perceived) level of quality of the service provided, with similar consequences. A third motivation for sunk costs arises from the deposit side. By offering deposit customers more conveniently located and/or faster services, a bank may be able to attract deposits at lower interest rates. This is an interesting proposition that warrants better attention than is possible within the scope of this paper. We do not model the deposit side explicitly in this paper, but control for the deposit interest rate(s) in the empirical model by treating it as an endogenous explanatory variable.

Our modeling framework encompasses two sub-models, a monitoring model and a product differentiation model, and is based on earlier work (Williamson, 1986, 1987, Shaked and Sutton, 1982). In the monitoring model, a bank can acquire a monitoring technology that can be used to test loan applicants for a pay-off relevant characteristic. The nature of the debt contract is such that it allows banks "to focus their attention on information gathering to a particular set of issues: those associated with the probability of default and the net worth of the firm in those low-return states" (Stiglitz 1985, p. 143). Therefore, the idea here is simply that the banks can spend resources in order to be able to inspect the entrepreneurs before granting loans and thereby produce information about the liquidity of the project in the state of default. ${ }^{5}$ The ability to increase loan receipts in states of default, i.e., to enhance the recovery rate of loans, can have important ramifications; in the Stiglitz-Weiss -type credit-rationing framework of Rousseau (1998) for instance, it leads to a lower loan-deposit spread and eventually to financial deepening. The recovery rate of loans is also an important input in modern credit risk models, such as J.P. Morgan's CreditMetrics or Credit Suisse's CreditRisk ${ }^{+}$.

\footnotetext{
${ }^{5}$ Wang and Williamson (1998) argue (and provide casual evidence) that such ex ante monitoring involves larger investments than ex post monitoring (costly state verification).
} 
The second version of the model is a product differentiation model close in spirit to Shaked and Sutton $(1982,1983)$, aimed at capturing a variety of frictions in bank customer mobility. The differentiation is thought to reflect financial service quality, bank-customer relationships and/or switching costs, though it could alternatively be interpreted as a combined model of differentiation and interim bank monitoring. In this model, banks can invest in activities that increase (decrease) the utility that entrepreneurial customers derive from buying their products (or from being in control of a project).

After having presented the two theoretical models we build an econometric model that encompasses both; and test the models' predictions using data from Finnish cooperative banks. These banks are small local banks operating in geographically distinct, non-overlapping markets. They share several common features like the ownership form, and a quasi-central bank. As a group, they have by far the largest branch network, suggesting that they have made sunk investments. Although these banks share many features and institutions, they operate independently. The common features, discussed in more detail in Section 3, suggest that they use e.g. their branches for the same purpose, be it information acquisition or market power. This is important in that our model suggests that banks can in equilibrium be either non-monitors or monitors, or have either high or low quality. A random sample of banks might lead to wrong inference of the role of sunk costs. Essentially, having banks that have a common mode of operation and that operate in separate markets enables us to identify empirically the role of sunk costs. ${ }^{6}$ Variation in local conditions across regions, and within regions over time

\footnotetext{
6 One way to deal with this would be to estimate different equations for monitoring and nonmonitoring banks using e.g. switching regressions.
} 
(see Section 3) allows us to measure the effect of branches and personnel on bank performance.

The remainder of the paper is organized as follows: in the next Section, we present and solve the two theoretical models, and discuss their empirical implications. We wish to emphasize that the models are purposefully rather stylized. Accordingly, they are to be regarded as examples of formal models from which the (general) hypotheses tested in the empirical part can be generated. In Section 3, we present and discuss the data. Section 4 provides our econometrics, and empirical results. In Section 5 we offer brief conclusions.

\section{The Theoretical Model}

\subsection{The Modeling Framework}

Consider a universally risk-neutral economy with two banks and a continuum of entrepreneurs distributed (with unit density) over a compact subset $D$ of $\Re^{2}$. Each entrepreneur has an initial endowment of $W>0$ which she can invest either in a safe project providing a payoff $W^{*}>W$, or in a risky project requiring an initial investment of size $K>W$. If the risky project is undertaken, it yields a random cash flow $X$. To initiate the risky project, an entrepreneur must raise finance $K-$ $W \equiv 1$. The two banks are the only source of outside finance for entrepreneurs in this economy and the banks are only willing to buy standard debt contracts, denoted by a pair $(1, R)$, where 1 is loan size and $R$ is the entrepreneur's payment if the project succeeds. The safe and risky projects are mutually exclusive. Banks obtain loanable funds at a constant cost denoted $\rho$.

The cash flows generated by the risky projects are drawn from the same probability distribution for all entrepreneurs. We denote with $x$ the realized return 
of a project; with $f(x)$ and $F(x)$ respectively the probability density (pdf) and cumulative density functions (cdf) of this distribution. The distribution $f(x)$ is assumed to be positive and differentiable on $[0, \infty)$. As in Williamson $(1986,1987)$, a cash flow realization $x$ is costlessly observable to each entrepreneur whereas a bank can observe it only by paying an auditing cost. We further assume that despite auditing the bank can confiscate only $x-v, v \geq 0$, where $v$ represents a leak to outsiders (plus the auditing cost) in states where the entrepreneur fails to meet her debt service obligation. The amount of this leak varies over the cross-section of entrepreneurs and banks know (for free) only the distribution of $v$ (see below). One may think of $v$ as a determinant of the recovery rate of loans and/or bankruptcy costs, i.e., general liquidation costs, legal fees, costs of selling specialized equipment and other costs that are deducted from the proceeds that should go to debtors. Borrowers cannot credibly reveal the value of $v$ to lenders.

We assume that the continuum of observationally identical entrepreneurs consists of types that can be characterized by an ordered pair $(v, \theta)$, where $\theta \geq 0$. Thus, firstly, the entrepreneurs differ w.r.t. $v$, the payments made to third parties in bankruptcy states. In particular, $v$ is distributed according to marginal pdf $g(v)$ with cdf $G(v)$, and has support $[0, \bar{v}], \bar{v}>0$. Secondly, the entrepreneurs value the quality and availability of bank services. The extent to which an entrepreneur values them depends on a characteristic $\theta$ which is a non-negative real number. It is assumed that this parameter is distributed according to marginal pdf $z(\theta)$ with $\operatorname{cdf}$ $Z(\theta)$ on $[0, \bar{\theta}], \bar{\theta}>0$.

A complementary interpretation for $\theta$ is that the project generates, besides the random and eventually verifiable cash flow, a sure, non-verifiable and nonassignable control rent that varies over the cross-section of borrowers. In such a model, bank quality is then to be interpreted as the tightness of bank's interim 
monitoring. The more intensively a bank monitors its client during the lending relationship, the less the borrower can enjoy the control rents that running an entrepreneurial project generates. Though combined effects (of financial service quality and interim monitoring) are likely to be present in actual borrowing decisions, we shall for brevity stick to the product differentiation interpretation in what follows.

The following assumptions hold throughout the analysis:

Assumption A1. The random cash flows are drawn from an Exponential distribution, i.e., $X \sim \operatorname{Exp}(\lambda)$ with support $[0, \infty)$ and the expected value $E(x)$.

Assumption A2. The characteristics $\theta$ and $v$ are statistically independent. In this economy, each possible value of the two parameters $v$ and $\theta$ is realized, and $\mathrm{G}(\hat{v})$ and $\mathrm{Z}(\hat{\theta})$ are the fractions of entrepreneurs with $v$ and $\theta$ parameter values $v \leq \hat{v}$ and $\theta \leq \hat{\theta}$, respectively. The marginal distribution for $\theta$ and $v$ is a Uniform distribution, i.e., $\theta \sim \mathrm{U}[0, \bar{\theta}]$ and $\mathrm{v} \sim \mathrm{U}[0, \bar{v}]^{7}$

To complete the description of our general modeling framework, we model a two-stage game. In the first stage, banks enter simultaneously and can make a costly investment of fixed size. If made, this (sunk) investment either allows them to test customers for their $v$, or to produce a high(er) quality service. In the second stage, banks compete for entrepreneurs by announcing independently -but sequentially- their loan interest rates. We assume that in this stage, whenever the banks' first stage decisions are not identical, the bank who made a (larger) sunk

\footnotetext{
${ }^{7}$ We would like to emphasize the following: Assumption A1 is imposed for the sake of concreteness. This seems justifiable since on the one hand, our analysis does not seem to be particularly dependent on the specific form of $f(x)$ we postulate. On the other hand, the cost of using a general $f(x)$ (with certain restrictions) is that explicit expressions for equilibrium interest rates cannot be derived. Though the independence assumption (Assumption A2) has no relevance in the monitoring model, it does simplify the product differentiation model in the sense that the provision of higher quality banking services does not affect the expected bankruptcy costs in a bank's loan portfolio.
} 
investment, gets to move first with probability $\alpha$, i.e., to announce its interest rate(s). The other bank is then able to observe these, takes them as given and chooses its own interest rate(s). With probability $(1-\alpha)$ the roles are reversed. Sequential second stage competition is adopted since no pure strategy Nash equilibrium exists in a simultaneous move loan pricing game with (asymmetrically) monitoring banks (for a model exhibiting a similar feature with partially overlapping customer classifications, see Broecker, 1990). As we will see, the realization of these leader-follower roles will play a major part in the equilibrium strategies of the banks. We begin with the monitoring model and thereafter analyze the Shaked-Sutton type model of vertical product differentiation.

\subsection{The Monitoring Model}

We first describe the nature of the monitoring technology and then derive Nash equilibrium loan pricing strategies as a function of banks' monitoring investments, and conditional on the realization of the leader-follower roles. Finally, we characterize the sub-game perfect monitoring decisions.

The Monitoring Technology: In order to keep the analysis tractable, we will restrict ourselves to a dichotomous monitoring variable which takes either the value $s^{m}>0$, or 0 . When this investment is made, two classes of entrepreneurs are created: categories for the good $(G)$ and the bad $(B)$ entrepreneurs. Specifically, by paying a strictly positive fixed fee $C^{m}$, the bank can identify whether an entrepreneur is of better or of worse type than $s^{m},{ }^{8}$ implying that the interval $[0, \bar{v}]$ is

\footnotetext{
${ }^{8}$ The threshold $s^{m}$ is common to both banks.
} 
divided into two subintervals by the insertion of point $s^{m}$ such that $0<s^{m}<\bar{v} .^{9}$

Note in particular that in this Section no quality difference between banks emerges. We therefore normalize the level of banks' service quality to zero.

The above implies that there are two possibilities to consider: A bank having no monitoring ability (NM-bank) must treat its customer population as a single entity, $G B \equiv G \cup B$, to whom it quotes a single rate $R_{N M}$ (one plus interest rate). A monitoring bank (M-bank) is able to tell whether a given entrepreneur belongs to $G$ or to $B$, and it could therefore quote two distinct interest rates: $R_{M, G}$ and $R_{M, B}$, one for each entrepreneur category. Let $v(p)$ denote the average (expected) $v$ in entrepreneur category $p=\{B, G B, G\}$. Clearly, for $s^{m}>0$, we have $v(G)<v(G B)<v(B)$.

We make the following technical assumption to simplify the analysis:

Assumption A3. In case both banks offer the same interest rate, an entrepreneur chooses with probability one the bank that has allocated her to a better category. If she is labeled identically by both banks, and the banks charge the same interest rate, she chooses a particular bank with probability $1 / 2$.

The banks are not allowed to cross-subsidize between entrepreneur groups. It is further assumed that if a bank has invested in ex ante monitoring, it carries out its evaluation and truthfully reports the monitoring result to each entrepreneur

\footnotetext{
${ }^{9}$ Of course, alternative assumptions on the nature of the monitoring technology could also be made. For instance, allowing for more entrepreneur categories (to be created similarly by both banks) would enlarge the strategy space a bank can consider when setting (specific) rates for different customer categories. However, this extension would increase the length of analysis via increasing the number of cases that would need to be considered both in Stages 1 and 2 of the game. Moreover, if in this environment a bank can acquire a technology which allows it to create another category, the analysis would correspond very closely to that pursued in this paper. Another alternative would be to postulate a continuous monitoring variable such that, say, all good entrepreneurs with a small $v$ could be perfectly identified. Not surprisingly, this creates technical problems as a bank no longer chooses a finite number of interest rates but rather designs an optimal interest rate offer function during the second stage of the game. In particular, when acting as the price leader, the design of such an offer function is rather involved and thus beyond the scope of the present paper.
} 
before announcing its loan rates. However, the banks cannot observe the outcome of the monitoring activity of their competitor, and a monitoring report by a rival bank is not verifiable. Thus, an entrepreneur cannot credibly reveal the monitoring outcome (loan offer) of bank $i$ to bank $j$. Note that ex ante monitoring reduces neither the ex post need for auditing nor the costs associated with it.

Loan Pricing Under Symmetric Monitoring Investments: If both banks invest in monitoring, competition will be Bertrand (with homogenous goods) in both entrepreneur groups $B$ and $G$; the situation is similar if neither bank invests in monitoring, the only difference being that both banks only offer one interest rate applying to all borrowers. Because of Bertrand competition, each bank is forced to compute the most competitive interest rate offer it can possibly make for the entrepreneurs in category $p$ as

$$
\max _{R} \mu(R)=\int_{R}^{\infty}(x-R) f(x) d x=E(x) e^{-\lambda R}
$$

subject to the individual rationality constraint of the bank:

$$
\begin{aligned}
\pi(R, v(p)) & =n(p)\left[\int_{R}^{\infty} R f(x) d x+\int_{0}^{R}(x-v(p)) f(x) d x-(1+\rho)\right] \\
& =n(p)\left((E(x)-v(p))\left(1-e^{-\lambda R}\right)-(1+\rho)\right)=0
\end{aligned}
$$

where $\mu(R)$ is the expected utility of an entrepreneur, $n(p)=\left(1-G\left(s^{m}\right)\right)$ if $p=B$ and $n(p)=G\left(s^{m}\right)$ if $p=G$ and $\pi(R, v(p))$ is a bank's return from loans granted at rate $R$ to entrepreneurs in category $p$. Note that $\mu^{\prime}(R)=-e^{-\lambda R}<0$ and $\pi^{\prime}(R, v(p))=(E(x)-v(p)) \lambda e^{-\lambda R}>0$. Thus, unlike in Williamson (1987), there is no credit rationing despite the presence of costs in verifying adverse project outcomes.

An entrepreneur's participation constraint is satisfied as long as the rate charged is below a "monopoly" rate, $R$, given by

$$
R^{*}=E(x) \ln \left(E(x) / W^{*}\right)
$$


where (by assumption) $E(x)>W^{*}$. In order to ensure that the banks' individual rationality constraint is not violated for any entrepreneur category (if financed at the monopoly interest rate) we assume that

$$
\bar{v}<E(x)\left[1-\frac{(1+\rho)}{E(x)-W^{*}}\right] .
$$

This condition ensures that entry deterrence is not a feasible form of pre-emptive market behavior. It is also sufficient to ensure the logical consistency of the zero profit interest rate, $R_{v(p)}^{0}$, defined as the interest rate at which a bank financing only customer pool $p$ makes zero expected profits. This is given by

$$
R_{v(p)}^{0}=E(x) \ln \left[\frac{E(x)-v(p)}{E(x)-v(p)-(1+\rho)}\right]
$$

for $p \in\{G B, G, B\}$.

As competition is Bertrand, both banks announce $R_{v(p)}^{0}$ for each conceivable $p$. Since both banks offer the same interest rate, and it is the lowest an entrepreneur is offered, a particular bank is chosen with probability $1 / 2$. Clearly, the banks make zero expected profits.

Loan Pricing Under Asymmetric Monitoring Investments: The M-bank has more competitive instruments than the NM-bank. Interestingly, the realization of the leader-follower roles determines to what extent the M-bank separates the two customer groups in equilibrium:

Proposition 1. Consider the sequential interest rate game in the case of asymmetric monitoring investment and conditional on the realization of the leaderfollower roles. Then, in the unique Nash equilibrium

(a) The M-bank as the (price) leader quotes a single' indifference rate', $R_{M, G}=R_{G}^{\text {ind }}$, for the entrepreneurs it classifies good and prices out the entrepreneurs it classifies bad. The NM-bank names the monopoly rate, $R_{N M}=R^{*}$, 
and finances at this rate all those entrepreneurs the M-bank has classified as bad. Both banks make positive expected profits. The interest rates are given by

$$
\begin{aligned}
& R_{G}^{\text {ind }}=E(x) \ln \left[\frac{E(x)-v(G B)}{E(x)-v(G B)-(1+\rho)-\pi\left(R^{*}, v(B)\right)}\right] \\
& R^{*}=E(x) \ln \left[\frac{E(x)}{W^{*}}\right]
\end{aligned}
$$

where $\pi\left(R^{*}, v(B)\right)$ is the profit that the NM-bank earns from category $B$ at the monopoly rate;

(b) as the (price) follower, the M-bank names $R_{M, G}=R_{M, B}=R_{v(B)}^{0}$ while the NMbank as the leader quotes $R_{N M}=R_{v(B)}^{0}$. The M-bank extends more loans than the NM-bank, i.e., it captures all the customers it has identified as good and half of those labeled bad. Only the M-bank makes positive expected profits. The equilibrium interest rate is given by equation (3) (with $p=B$ ).

Proof. In Appendix 1.

The M-bank always earns positive expected profits (only) from the group of good entrepreneurs. Despite this, good borrowers pay on average a lower interest rate for their loans than bad customers. As the leader, the M-bank designs an interest rate schedule that provides a price umbrella under which the NM-bank may set its rate. This "bribery pricing" softens the undercutting strategy of the nonmonitoring follower and takes the form of pricing out the group of bad entrepreneurs. The result is close to the finding of Chan and Thakor (1987) who somewhat surprisingly find that high-quality borrowers may be priced out of the market (but not explicitly denied credit) despite a bank having idle deposits. This way of pricing loans strongly differs from the situation in which M-bank is the follower: in such a credit market loan customers are effectively offered a pooling contract despite the bank's ability to discriminate between them. Finally, from the per- 
spective of the NM-bank, there is a positive spillover from the monitoring investment of its rival: despite Bertrand competition and homogenous products the NMbank earns positive expected profits in equilibrium if $\alpha \in(0,1]$, i.e., if there is a positive probability that the M-bank is the leader.

The Monitoring Investment: Consider the simultaneous entry of the banks and assume that the sunk investment generating monitoring services is feasible, i.e., that the fixed cost $C^{m}$ is low enough to motivate the acquisition of the monitoring ability at least by one bank. As long as this assumption holds, the following obtains: Proposition 2. The monitoring model has an asymmetric sub-game perfect equilibrium in which only one bank invests in monitoring.

The reason for this is that identical investments lead to Bertrand competition and zero profits, whereas with one bank investing in monitoring, both make strictly positive expected profits for $\alpha \in(0,1]$. Note that the equilibrium is unique up to the reversal of banks' indices. ${ }^{10}$

We can now state the empirical predictions of the monitoring model. In a given banking market, the equilibrium structure is asymmetric with one monitoring bank. Note that irrespective of the nature of the sequential interest rate game, M-bank ends up financing entrepreneurs with a lower average $v$ than NM-bank. Moreover, as long as there is a positive probability that the M-bank is the market leader, it also finances its borrowers on average at a lower interest rate than the NM-bank. As the M-bank's customers have a lower average $v$ than the customers of the NM-bank, the M-bank will have lower bankruptcy costs (even) after controlling for interest rates. Let us summarize these predictions as

\footnotetext{
${ }^{10} \mathrm{We}$ have also analyzed the case when banks enter the market sequentially, and the entry order is random. In such a case, one can derive a threshold level that determines whether the bank entering first or last invests (does not invest) in monitoring.
} 
Corollary 1. The M-bank charges on average lower interest rates and, conditional on the interest rates charged, faces smaller credit losses relative to the amount of loans extended, than the NM-bank. ${ }^{11}$

\subsection{The Product Differentiation Model}

In this sub-section the sunk investment changes the way loan customers perceive the services a banking firm provides. Both for simplicity and to create comparability to the monitoring model we let the quality and availability of services of a bank be a dichotomous variable, i.e., it is either $s^{q}>0$ or 0 . The cost of this investment is fixed, $C^{q}>0$. None of the results in this section are due to the constrained choice set the banks face but rather can also be derived for a continuous quality variable.

As previously, we next derive Nash equilibrium loan pricing strategies of banks as a function of service quality investments and conditional on the realization of the leader-follower roles. Finally, we find the sub-game perfect quality investments.

Loan Pricing Under Symmetric Quality Investments: Since in this section no monitoring is involved, the banks can observe neither $v$ nor $\theta$ characterizing the entrepreneurs and each bank can only quote one interest rate applying to all entrepreneurs. It follows that if both (neither of the) banks have made the sunk quality investment, there is no difference in customers' quality perceptions. The analysis then corresponds to the case of pure Bertrand competition, and the characterization of the previous section holds.

\footnotetext{
${ }^{11}$ These empirical predictions are not specific to our model of information acquisition. E.g. Rousseau's (1998) model predicts that a bank that invests in new technology will (temporarily at least) charge lower interest rates and have lower defaults. Also, Toivanen (1998) obtained equivalent predictions about the effect of ex-ante monitoring in a Rothchild-Stiglitz-type model (of insurance purchasing) with the possibility of firms investing in an information acquisition technology. In his model, the monitoring insurer set lower premiums, and its customers had fewer accidents.
} 
Loan Pricing Under Asymmetric Quality Investments: In this subsection, we consider the asymmetric case in which only one bank has made the quality related sunk investment. To begin with, let $R_{H}$ and $R_{L}$ denote the rates charged by the high-quality (H-bank) and low-quality bank (L-bank), respectively. An entrepreneur with characteristics $(v, \theta)$ patronizing the H-bank has expected utility

$$
\mu\left(R_{H}\right)+s^{q} \theta
$$

where $\mu\left(R_{H}\right)=E(x) e^{-\lambda R_{H}}$. Given the normalization of the quality variable, the expected utility for customers of the L-bank is simply $\mu\left(R_{L}\right)=E(x) e^{-\lambda R_{L}}$. A marginal entrepreneur type $\left(\theta^{*}\right)$ who is indifferent between patronizing the two banks is given by

$$
\theta^{*} \equiv \frac{\mu\left(R_{L}\right)-\mu\left(R_{H}\right)}{s^{q}}
$$

For the L-bank to attract any customers, $R_{L}<R_{H}$ must hold. Since $\theta \sim \mathrm{U}[0, \bar{\theta}]$, the demands the banks face are $D_{H}\left(R_{H}, R_{L}\right)=1-\theta^{*} / \bar{\theta}$ and $D_{L}\left(R_{H}, R_{L}\right)=\theta^{*} / \bar{\theta}$ for the H-bank and L-bank, respectively.

Bank $i$ 's expected profits are given by

$$
\pi\left(R_{i}, v(G B)\right)=D_{i}\left(R_{i}, R_{j}\right)\left((E(x)-v(G B))\left(1-e^{-\lambda R_{i}}\right)-(1+\rho)\right)
$$

where $i=H, L, i \neq j$.

Due to the assumed sequential structure in interest rate setting, we (again) have two asymmetric cases to consider: the cases of H-bank as the leader and follower. Since by Assumption A2 $v$ and $\theta$ are independent, a service quality difference between banks does not (as such) change in a systematic way the expected bankruptcy costs a bank faces. We have: 
Proposition 3. Consider the sequential interest rate game in the case of asymmetric quality investment and conditional on the realization of the leader-follower roles. Then, in the unique Nash equilibrium

(a) the H-bank as the (price) leader quotes

$$
R_{H}=E(x) * \ln \left[\frac{E(x)-v(G B)}{E(x)-v(G B)-(1+\rho)-\left(1-v(G B)(E(x))^{-1}\right) s^{q} \bar{\theta}}\right]
$$

while the L-bank (as the follower) names

$$
R_{L}=E(x) * \ln \left[\frac{E(x)-v(G B)}{E(x)-v(G B)-(1+\rho)-\frac{1}{2}\left(1-v(G B)(E(x))^{-1}\right) s^{q} \bar{\theta}}\right]
$$

The associated loan demands are $D_{H}=\frac{1}{2}$ and $D_{L}=\frac{1}{2}$ for the H-bank and the L-bank, respectively. Both banks make positive expected profits.

(b) the H-bank as the (price) follower quotes

$$
R_{H}=E(x) * \ln \left[\frac{E(x)-v(G B)}{E(x)-v(G B)-(1+\rho)-\frac{3}{4}\left(1-v(G B)(E(x))^{-1}\right) s^{q} \bar{\theta}}\right]
$$

while the L-bank (as the leader) names

$$
R_{L}=E(x) * \ln \left[\frac{E(x)-v(G B)}{E(x)-v(G B)-(1+\rho)-\frac{1}{2}\left(1-v(G B)(E(x))^{-1}\right) s^{q} \bar{\theta}}\right]
$$

The associated loan demands are $D_{H}=\frac{3}{4}$ and $D_{L}=\frac{1}{4}$ for the high-quality follower and the low-quality leader, respectively. Both banks make positive expected profits.

A sketch of the proof can be found in Appendix 2 where we also give the expressions for the expected equilibrium profits.

The Quality Investment: The analysis of the first stage of the vertical product differentiation game closely parallels that of the monitoring game. Here, we again assume that the sunk investment generating customer services is feasible, i.e., that its fixed cost $C^{q}$ is low enough to induce one bank to invest in qual- 
ity. Because the two banks want to avoid entering price competition in Bertrand fashion (in homogenous goods), it is easy to verify that with simultaneous entry, there exist two asymmetric sub-game perfect equilibria:

Proposition 4. The vertical product differentiation model has an asymmetric subgame perfect equilibrium in which only one bank invests in quality. ${ }^{12}$

We can now turn to the empirical predictions of the market power version of our model. As in the information acquisition version, the equilibrium structure of a given banking market is asymmetric with one bank investing in high(er) loan customer convenience. The H-bank on average ends up extending more loans and financing entrepreneurs at a higher interest rate than the L-bank as long as $\alpha \in[0,1)$. Since the average $v$ in the loan portfolios of both banks is $v(G B)$, expected bankruptcy costs (relative credit losses) are identical for the two banks after controlling for interest rates. Let us summarize these empirical predictions as Corollary 2. The H-bank charges higher interest rates and extends more loans than the L-bank. Conditional on interest rates charged, both banks face identical credit losses relative to the amount of loans extended.

In Section 4 we will turn to the empirical specification of our model. The next Section discusses the market, and the data.

\footnotetext{
${ }^{12}$ As in the monitoring model, when allowing for sequential entry, a threshold can be derived that determines whether the bank entering first invests (does not invest) in quality.
} 


\section{The Finnish Banking Market, and the Cooperative Banks}

\subsection{The Data and Market Environment}

Currently, partly as a result of the severe economic crisis in Finland in the early 90's, the Finnish banking market is dominated by a few bank(ing group)s, one of which consists of over 250 local cooperative banks. Our sample consists of these banks (bar a few exclusions). The other traditional group of local banks, the savings banks, were the most prominent victim of the banking crisis, and have dramatically reduced in size as a consequence of a) a large merger between them and b) a splitting of the merged bank between the remaining banking groups (in 1993). As a result of mergers, the three main banking groups in Finland consist of the group of cooperative banks on which we here concentrate, and two commercial banks operating on the national level (i.e., that have a nationwide branch network). Several studies (e.g. Koskenkylä and Vesala, 1994, Nyberg and Vihriälä, 1994, Davis, 1995) describe the events before and during the crisis, so we will offer only a synopsis here. The volume of lending grew very rapidly (at times by over $30 \%$ p.a.) in the late 80 's, partly due to financial market liberalization that took place in the mid-80's, partly due to an economic boom and lax monetary policy. The boom ended in a collapse of asset values including real estate (a prime source of collateral), and the economy shrank by $8 \%$ in $1992-1994$. The economy has been growing since then. The government bailout of banks has been estimated to cost 50 billion FIM. 
Table 1.

Nationwide branch networks of Finnish banks/banking groups

\begin{tabular}{|cccc|}
\hline & Cooperative banks & Merita & Savings banks \\
\hline 1993 & 977 & 673 & 859 \\
1994 & 993 & 776 & 248 \\
1995 & 960 & 619 & 250 \\
1996 & 893 & 479 & 242 \\
\hline
\end{tabular}

Note: The figure of Savings banks in 1993 includes Savings Bank of Finland that was dismantled by the end of 1993. Figures provided by the Finnish Bankers' Association.

A comparison of the nation-wide branch networks of different banking groups (see Table 1) reveals that as a group, the cooperative banks have by far the largest branch network. ${ }^{13}$ It is clearly larger than that of the other group of local banks, the savings banks. The branch network of the largest Finnish bank, Merita, is roughly two thirds or less of that of cooperative banks. This supports our (implicit) assumption that these are banks that have made (larger) sunk investments. ${ }^{14}$

Cooperative banks are mostly small, local banks that share a common organizational form and some institutions (they own a "central bank", have an association that collects and disseminates information, and share other facilities usually found in the headquarters of a bank). Though most decision making power is at the level of individual banks, group coherence and guidelines from the common bodies affect sometimes strongly the behavior of individual banks. During the boom years of the late 1980's the cooperative banks were among the conservative: as an example, the volume of their lending grew less than that of deposit banks on average. They also experienced a smaller surge in the amount of bad loans during the crisis in the early 1990’s (see, e.g., Koskenkylä and Vesala, 1994). Compared to other banking groups, cooperative banks are clearly more focused on private

\footnotetext{
13 Of the comparison banks/banking groups, SBF was created by a merger of most local savings banks, and was dismantled in 1993. Merita is the largest bank in Finland, formed through a merger of the two (previously) largest banks. The branch networks of the two largest banks have been added together in the table to allow comparisons, and as such Merita's figures represent an upper bound.
} 
customers, agriculture, and small business. ${ }^{15}$ As a matter of fact, cooperative

banks are the biggest source of loans to agriculture. ${ }^{16}$

Table 2.

Descriptive statistics of bank level data

\begin{tabular}{|c|c|c|}
\hline Variable definition & Mean & St.Dev \\
\hline DEP $=$ The amount of deposits in year $\mathrm{t}$, in Million FIM & 293.56 & 486.47 \\
\hline LOAN $=$ The amount of credit market loans in year $t$, in Million FIM & 258.47 & 474.90 \\
\hline $\begin{array}{l}\mathrm{R}_{\mathrm{D}}=\text { Deposit interest rate in year } \mathrm{t} \text {, calculated as interest rate ex- } \\
\text { penses/amount of deposits }\end{array}$ & 0.0390 & 0.0184 \\
\hline $\begin{array}{l}\mathrm{R}_{\mathrm{L}}=\text { Loan interest rate in year } \mathrm{t} \text {, calculated as interest rate income/amount } \\
\text { of outstanding loans }\end{array}$ & 0.0933 & 0.0166 \\
\hline $\begin{array}{l}\mathrm{R}_{\mathrm{DM}}=\text { Interbank market deposit interest rate in year } \mathrm{t} \text {, calculated as inter- } \\
\text { est rate expenses/amount of interbank market deposits }\end{array}$ & 0.0650 & 0.0194 \\
\hline RDEP = Ratio of deposits to total funding & 0.8551 & 0.0851 \\
\hline $\begin{array}{l}\mathrm{R}_{\mathrm{LM}}=\text { Interbank market loan interest rate in year } \mathrm{t} \text {, calculated as interest } \\
\text { rate income/amount of outstanding interbank market loans }\end{array}$ & 0.0556 & 0.0216 \\
\hline $\begin{array}{l}D E F R=\text { Net charge-offs in year t/amount of outstanding loans in } \\
\text { year } t . \text { In the estimations we use } D E F=\ln (0.000001+D E F R)\end{array}$ & 0.0141 & 0.0201 \\
\hline $\begin{array}{l}\mathrm{BRA}=\text { The number of branches at the beginning of year } \mathrm{t} \text { divided by the } \\
\text { size (in square kilometers) of the market area }\end{array}$ & 0.0079 & 0.0157 \\
\hline $\begin{array}{l}\text { PERS }=\text { The amount of personnel expenses in year } t \text {, in Million FIM di- } \\
\text { vided by the number of branches at the beginning of year } t\end{array}$ & 3.2621 & 6.2004 \\
\hline INEFF = Ratio of non-interest expenses in year $t$ to non-interest revenues & 0.7126 & 0.3012 \\
\hline $\begin{array}{l}\text { SBFD = Dummy variable taking value of } 1 \text { for } 1993-1995 \text { if the bank } \\
\text { bought a part of the dismantled SBF-bank in } 1993\end{array}$ & 0.3104 & 0.4628 \\
\hline
\end{tabular}

We have data on 250 cooperative banks over the period 1992-1996. We use a relatively short and recent panel to exclude the 80 's, as the consensus view is that banks then had not yet learned to operate in a liberalized environment. Another reason is to allow time for banks to adjust their branch networks and personnel to levels that are optimal under deregulated conditions; such adjustments necessarily take time. The descriptive statistics of our sample are given in Table 2. Although

\footnotetext{
${ }^{14}$ The second remaining nation-widely operating bank (besides Merita) is excluded from the table. The reason for this is that it is the government owned former postal savings bank. It has clearly the smallest number of own branches, but does provide (some) services through post offices.

${ }^{15}$ The cooperative banks were originally established to channel government loans to small farms which had difficulties getting loans from established banks. This was the main line of business until the 1950's (personal correspondence with Antti Kuusterä. Kuusterä is a historian who has written a book on the history of savings banks, and is currently writing a book on the history of the cooperative bank). The cooperative banks' joint market share of SME lending is circa $40 \%$.

${ }^{16}$ The prevailing legislation has guaranteed the loans made to farms. These therefore do not expose banks to credit risk.
} 
these banks share several features, they are a rather diversified group: the smallest bank's loans amount to just over 6 Million FIM whereas the largest one's are almost 4000 Million FIM (circa $\$ 800$ Million using the average 1998 exchange rate), with the mean at 257 Million. ${ }^{17}$ On average the banks seem to have slightly higher deposits (mean 284 Million) than loans. We have calculated four interest rates; two are revenues (loans, and loans made (mainly) to other banks (inter-bank lending)). The latter also contains revenues from investments in government bonds etc.), two are costs (deposits, and loans from other banks (inter-bank borrowing)). It is clear from Table 2 that the deposit interest rate is lower than that of inter-bank borrowing, although there is bank-level variation. The reverse applies for loans granted. Banks receive a clearly higher interest rate for loans granted to customers, than from inter-bank lending. One of the variables of most interest in this study is the level of default costs; they are measured by net charge-offs, i.e., the difference between loans actually written off and recoveries from loans previously categorized as uncollectible. As e.g. in Angbazo (1997), it will serve as a proxy for asset quality and expected defaults (relative credit losses) and we have calculated it as a percentage of loans given (excluding inter-bank loans). The percentage of default costs $\left(D E F R_{i t}\right)$ varies between 0 and $18.5 \%$, with a mean of 1\%. ${ }^{18}$ As pointed out earlier, in autumn 1993 the Savings Bank of Finland (SBF) was dismantled through a sale of parts of its balance sheet (loans and deposits) and branches to its rival banks (see, e.g. Vihriälä, 1997, for details). In our sample

\footnotetext{
${ }^{17}$ There has been some consolidation within the cooperative banks. Whenever two or more banks have merged, our data treats them as if they had merged prior to our observation period. A merger dummy did not come up significant in the estimations.

18 There are a few observations with a negative DEF. These are the result of recoveries and banks making reservations against future profits when customers default: in essence, the banks deduct from current period's profits their estimate of loss. If the loss is overestimated, the difference can be deducted from profits later on.
} 
97 banks were involved in this unloading operation of SBF. To control in estimations for the potential effects of this specific event, a SBF dummy (SBFD) is introduced (see Table 2).

As a measure of service accessibility/quality and banks' ability to gather local information, we use the number of branches at the beginning of the year per square kilometer $\left(B R A_{i t}\right)$. It varies between $1.212 * 10^{-5}$ and 0.154 (with a mean of 0.008). The idea behind this definition is that geographical proximity matters; if a bank operates in a geographically large market where the customers are disbursed, it is not enough to have a large branch at the center, if one wants to acquire information. The same applies for investments in quality: customers may value a large, geographically disbursed branch network that allows them easier access to services. To take into account that given geographical proximity, a branch is more effective in providing services and/or acquiring information, the more (and better trained) staff it has, we use as another measure of sunk costs personnel expenses per branch $\left(P E R S_{i t}\right)$. It varies from 0.018 to 61.014 Million FIM per branch.

The macroeconomic conditions vary markedly over our observation period. We have therefore checked the year-wise descriptive statistics of our banking variables for any anomalies and/or outliers (without finding any; see Appendix 2).

As to the operating environment of cooperative banks, they operate in different, non-overlapping markets. These markets are well defined, i.e., in line with what the banks themselves do, a bank's market is identified to consist of those counties in which it has branches. Typically, there are only very few competitors in the market so that competitive conduct is (in line with our theoretical model) approximately duopolistic. Most often the rival is either a savings bank, or one of the nationwide commercial banks, and only in larger cities is this approximation 
weaker. In Table 3 we present descriptive statistics of the markets the banks operate in. This demographic and sosio-economic data is available to us only for 19921995. As can be seen, the markets vary in terms of population (and its density), average wealth, in the number of farms (or the proportion of workforce employed in agriculture), unemployment rate, and average education level.

Table 3. Descriptive statistics of market level data

\begin{tabular}{|lrr|}
\hline Variable definition & Mean & St.Dev \\
\hline POPULAT = Total population & 18.197 & 36.575 \\
DENS = Ratio of population to the size (in square kilometers) of the area & 24.407 & 62.868 \\
OWNH = Ratio of persons living in their own house to total population & 0.298 & 0.025 \\
FARM = Number of farms & 484.445 & 516.401 \\
WCAP = Taxable wealth per capita & 52.248 & 11.773 \\
UN = Unemployment rate & 0.202 & 0.047 \\
STUDENT = Ratio of students to total population & 0.077 & 0.013 \\
$\begin{array}{l}\text { EDUC = Ratio of persons having an M.Sc./M.A. or a Ph.D. degree to total } \\
\text { population }\end{array}$ & 0.057 & 0.018 \\
AGRIC = Ratio of workforce working in farming, fishing and other agri- & 0.275 & 0.149 \\
$\begin{array}{l}\text { cultural industries to total workforce } \\
\text { SERCON = Ratio of workforce working in services, construction business }\end{array}$ & 0.322 & 0.106 \\
$\begin{array}{l}\text { and manufacturing industry to total workforce } \\
\text { OUTSIDE = Number of persons in employment inhabiting the market } \\
\text { area but working outside the area }\end{array}$ & 0.155 & 0.087 \\
\hline NOTES: data provided by Statistics Finland; period 1992-1995 & & \\
\hline
\end{tabular}

\subsection{Cooperative Banks, Profit Maximization, and Managerial Rent-seeking?}

A special issue relating to our data that needs to be discussed is the ownership form of the banks. One can plausibly argue that a cooperative bank's objective isn't (necessarily) to maximize profits, and in our theoretical model we assumed just that. There are several reasons why this seems to be a valid approach here. Firstly, only a relatively small portion of these banks' customers are actually 
members of the cooperative, i.e., owners of the bank. ${ }^{19}$ Treating non-member customers as if the bank was profit-maximizing (when serving them) seems to us a good first approximation. Secondly, these banks seem to behave no differently towards business customers than other banks, other than being more oriented towards small businesses. This in turn has a historical explanation, as the large firms in Finland have traditionally obtained finance through commercial banks. Thirdly, if there are any differences between the lending practices of commercial and cooperative banks, one would -both on historical and theoretical ground-expect the latter to be more risk-averse than the former. One would hence a priori expect them to be (if anything) more likely to invest in monitoring than commercial banks. Fourthly, regarding investments in product quality, such investments could well be in the interest of owner-customers, and a cooperative bank, too, would have to cover the cost of such investments through higher price-cost margins.

It is generally thought that the (owners') control of cooperatives' management is not as tight as that in profit maximizing institutions. Without attempting to model this explicitly, one could build an alternative hypothesis from the starting point that there are differences among cooperative banks in the extent to which the management can engage in rent-seeking activities like empire-building. On the one hand, if it is assumed that managing a larger bank leads to higher managerial rents, this would imply that banks with less strict control would have more branches and more (though not necessarily more qualified) personnel. On the

\footnotetext{
${ }^{19}$ In 1998 , less than $1 / 3$ (less than 700000 out of 2.1 million) of all 'active' customers were members, despite strong growth in the 90's (because of active recruiting: the cooperative banks' target is 1 million members by 2002). Some $5 \%$ of members are firms or societies (e.g. sports clubs). The one-time membership fee was no less than 500 FIM (circa 100 USD) in 15\% of the banks in 1992; currently, it is more than 500 FIM for $40 \%$ of the banks. We have been told that there is strong variation between banks. Members have received miscellaneous benefits, the economically most important probably being the possibility buy a 'membership credit insurance policy' to be used as collateral. No clear policies have existed in terms of giving members loans on more beneficial terms.
} 
other, if one (further) measure of bank size is its loan portfolio (balance sheet), one could then argue that banks with less strict control would offer lower loan interest rates so as to maximize the size of the loan portfolio. Such a model would thus create a negative correlation between our measures of sunk costs and loan interest rates, and make the managerial rents model empirically undistinguishable from the information acquisition model with regard to the loan interest rate equation. It is however not clear that managerial rent seeking would have any implications on default costs, conditional on the loan interest rate(s) and the size of the loan portfolio. One can therefore use the default equation to separate empire building from information acquisition.

Another approach to acquire managerial rents would be to go for a 'quiet life'. The hypothesis would then be that such a bank makes small sunk investments and gives loans only to low-risk customers. This approach naturally raises the question of how the bank would recognize the low-risk projects: it could use e.g. collateral requirements. If leading a 'quiet life' is associated with few sunk costs and 'risk-averse' lending practices, one would expect a positive correlation between sunk costs and defaults. A quiet life, in any case, seems incompatible with empire-building. ${ }^{20}$

On balance, once one allows for the possibility of managerial rent seeking, it seems sensible to allow for heterogeneity among managers with respect to how they would exploit such opportunities. One could then hypothesize that all managers of cooperative banks have rent-seeking opportunities and that managers

\footnotetext{
${ }^{20}$ If one assumed that a manager can seek to build an empire and lead a quiet life simultaneously, this would lead to a predicted negative correlation between the size of the loan book, and defaults. Empire building implies a larger loan book; a quiet life that the bank (e.g. by requiring collateral) chooses low-risk customers. It is not clear what the effect of sunk costs, conditional on the size of the loan book, would be on default costs in such a setting. In any case, we find that (relative) default costs are increasing in the size of the loan book, rejecting the 'building an empire and leading a quiet life'-hypothesis.
} 
have idiosyncratic tastes, with some preferring a quite life and some empirebuilding. Those of the first type would run small banks with small sunk investments, and give out loans only to low-risk customers; those of the latter type would run large banks with large sunk investments, and give out a large number of loans. Such a model would create a positive correlation between sunk investments and default costs, and allow us to empirically distinguish managerial rentseeking from information acquisition. It is not clear what the predicted correlation between sunk costs and loan interest rates would be.

\section{$4 \quad$ Empirical Model and Results}

\subsection{The Empirical Model}

The empirical predictions of our theoretical model are expressed in the two corollaries in Section 2. There are two types of banks in a given banking market according to our models: those that have made a sunk investment and those that have not. Sunk investments may affect, firstly and most importantly for the empirics, the relative amount of defaults (negatively in case of monitoring, not at all in the case of market power investments), and secondly, the loan interest rate (negatively in case of monitoring investments, positively in case of market power investments). For the reasons discussed, we use the branch network and personnel costs as measures of a bank's sunk investments.

A central feature of our identification strategy is that our sample is special in that the banks operate in a similar way, and that they operate in different, nonoverlapping markets. Our model predicts that in a given market there are banks that do invest in sunk costs and banks that do not invest. Our data (see Table 1) 
supports the assumption that cooperative banks have made sunk investments. The common ownership form and other shared features suggest that they use their sunk investments for the same purpose(s), be it market power or information acquisition, or something else. Having similar banks that operate in different markets enables us to avoid having non-investing and investing banks, as well as investing banks that use their investments for different purposes, in the sample. ${ }^{21}$ Both of these would, according to our model, be unavoidable if our data consisted of all banks in a given market.

We estimate the following dynamic equations for defaults $\left(D E F_{i t}\right)$ and loan interest rates $\left(I N T L_{i t}\right)$ :

$$
\begin{aligned}
D E F_{i t} & =\alpha_{D} D E F_{i, t-1}+\beta_{D 1} L O A N_{i t}+\beta_{D 2} I N T L_{i t}+\beta_{D 3} I{ } E F F_{i t} \\
& +\beta_{D 4} B R A_{i t}+\beta_{D 5} P E R S_{i t}+\mu_{D i}+\gamma_{D t}+v_{D i t} \\
I N T L_{i t} & =\alpha_{I} I N T L_{i, t-1}+\beta_{I 1} L O A N_{i t}+\beta_{I 2} D E F_{i t}+\beta_{I 3} I N E F F_{i t} \\
& +\beta_{I 4} B R A_{i t}+\beta_{I 5} P E R S_{i t}+\beta_{I 6} I N T D_{i t}+\mu_{I i}+\gamma_{I t}+v_{I i t}
\end{aligned}
$$

where $t=1992, \ldots, 1996$ and $i=1, \ldots, 250$. In these equations, the $\gamma_{j t}(j=D, I)$ are time dummies, and $v_{j i t}$ are i.i.d. error terms. The time dummies should capture the effects of any economy-wide shocks on loan pricing and defaults. The $\mu_{j i}$ are firmspecific effects, possibly correlated with explanatory variables, which control for bank and market specific unobservables. The most important market (bank) specific unobservables are the (average) riskiness of loan customers and the average expected value of their projects, and (possibly) the scope for managerial rentseeking. To the extent to which behavioral patterns and competitive pressures of the rival banks are time-invariant, $\mu_{j i}$ controls also for the competitive situation of the market. As in the company investment application of Bond and Meghir

\footnotetext{
21 Note that defining empirically a 'non-investing' bank is difficult as any retail bank needs at
} least one branch, and some personnel to be operative. 
(1994), a further motivation for including bank-specific effects is that our sample is non-random; it includes cooperative banks only. By allowing for fixed effects, this particular persistent feature (and its implications for bank behavior) can to some extent be controlled for.

As to explanatory variables, the once lagged endogenous variables are included to capture any adjustment processes in banks' pricing behavior and gradual realization of loan losses. Variable $L O A N_{i t}$ is included to control for the size of a bank's loan book whereas $I N E F F_{i t}$ (ratio of non-interest expenses to non-interest revenues) is included as a summary variable to control for i) the (in)efficiency of management, ii) implicit interest rates (possibly) charged in the form of fees on loans and commissions and iii) income smoothing. Inefficiency in management potentially means higher operating costs (and therefore higher non-interest expenses) whereas the practice of charging implicit interest rates shows up in noninterest revenues. Income smoothing is present e.g. if loans are written off against abnormally high non-interest income and low operating costs. As these (mixed) effects are all represented by $I N E F F_{i t}$, and since this summary variable also probably proxies the extent to which banks are engaged in other operations besides traditional loan business, its sign is not predicted. The cost of funding, $I N T D_{i t}$, (calculated as a weighted average of interest rates on inter-bank borrowing and deposits) and the proxy for expected defaults, $D E F_{i t}$, are included in the interest rate equation and they are predicted to have positive coefficients. As discussed in the introduction, we do not model the deposit side, and deposit-market related reasons for sunk investments. $I N T D_{i t}$ controls for such effects were they to exist. Our theoretical model drives the inclusion of $I N T L_{i t}$ in the default equation, and its 
effect on defaults should be positive. The default equation also contains the SBFdummy. ${ }^{22}$

All variables are in logs, and since there are observations with zero values for $D E F R_{i t}$, we use $D E F_{i t}=\ln \left(.000001+D E F R_{i t}\right)$. We did experiment with different definitions of $D E F_{i t}$ (linear, $\left.\ln \left(1+D E F R_{i t}\right)\right)$, and our results are robust in this sense. The nominal values of variables are used. ${ }^{23}$

\subsection{Econometric Methods and Instrument Choices}

Our econometric model is dynamic; we have therefore chosen to estimate the model using Generalized Method of Moments (GMM) estimators designed for dynamic panel data (Arellano and Bond, 1991, Blundell and Bond, 1998, 1999). ${ }^{24}$ We report two different GMM estimates: GMM-DIF is the Arellano-Bond (1991) estimator, and GMM-SYS the Blundell and Bond (1998; see also Arellano and Bover, 1995) estimator. Based on the standard assumptions on the covariance structure of error components and on the initial conditions, the first one uses the twice and more lagged levels of endogenous explanatory variables as instruments in first-differenced equations. For predetermined variables, the once lagged levels of variables are also valid instruments. The second utilizes the assumption that the differences of the explanatory variables are uncorrelated with the firm-specific

\footnotetext{
22 The SBF-dummy was never significant in the interest rate equation and was therefore dropped.

${ }^{23}$ The reason for using nominal values is that $i$ ) it is not clear what deflator to use (e.g. real estate values both declined and increased during the observation period), ii) inflation was very low during the (short) observation period. We have however estimated the base specification using variables deflated by the consumer price index, and the cost of living index. The results did not change.

${ }^{24}$ Estimating a static model with Error Component 2SLS (Baltagi, 1981) produced similar results, but auto-correlation tests for the estimated residual suggested mixed conclusions. It should be noted, however, that these estimations were based on a set of covariance restrictions that were somewhat stronger than the ones adopted in this paper. These (exogeneity) restrictions were made to obtain valid instruments, and we did not test for their validity in that framework.
} 
effect (and a further initial condition assumption). This allows the use of suitable lagged first differences as instruments for the equations in levels. It has been shown (Blundell and Bond, 1998, 1999) both in Monte Carlo studies and empirically, that especially when the levels are weak instruments for the first differenced variables, considerable efficiency gains and avoidance of finite sample bias can be achieved by adding these extra moment conditions. Such a situation may arise especially when the time series are persistent. This is the case for a number of variables in our data, particularly for $P E R S_{i t}, B R A_{i t}$ and $L O A N_{i t}$.

In the GMM-DIF estimations of the default and loan equations, we have i) allowed for the fact that the lagged dependent variable is necessarily correlated with the bank-specific effects and ii) assumed that the levels of any other explanatory variable are potentially correlated with the bank-specific effects. In the default equation, the lagged dependent variable and $L O A N_{i t}$ are potentially correlated with $v_{\text {Dit }}$, i.e., endogenous. Since $D E F_{i t}$ represents realized loan defaults, the other remaining explanatory variables in this equation are assumed to be predetermined w.r.t. $v_{\text {Dit }}$. For the loan interest rate equation, a more conservative approach was adopted; there, all the explanatory variables are treated as endogenous. Based on this classification, the instruments used for GMM-DIF are thus the observations on explanatory variables dated $t-2$ and earlier if the variable is endogenous, and $t-1$ and earlier if it is predetermined.

In the GMM-SYS estimations, we initially assumed that the differences of all explanatory variables in both interest rate and default equations are uncorrelated with the bank-specific effects and specifically, that the deviations of the initial conditions from the (long-run) mean of the process are uncorrelated with the mean itself (Blundell and Bond 1998, 1999). The instruments used in the levels 
equations are the observations on the differenced explanatory variables dated $t-1$ (e.g. $\left.\Delta x_{t-1}\right)$ if the variable is endogenous and $t$ if it is predetermined.

The first observation of our sample is however special; on the one hand, in 1992 the banking crisis hit its deepest point, and for instance defaults for the whole Finnish banking sector reached their peak (during that year, 4,8\% of loans were written off; see Davis, 1995); on the other, the process of dismantling SBF took place in 1992 and 1993. Interestingly, the default costs for our sample were at their lowest in 1992, relative to loans extended (which also were at their minimum). This casts doubts on the validity of the initial conditions restrictions, at least for the $D E F_{i t}$ and $L O A N S_{i t}$ variables. Indeed, when we tested for all the additional moment conditions used in the levels equations, a difference-Sargan statistic rejected their validity at $1 \%$ level (p-value .0083) in the interest rate equation and yielded a p-value of .105 in the default equation. There are reasons to suspect that $\triangle L O A N_{i, t-1}$ and $\triangle D E F_{i, t-1}$ are the driving forces behind the rejection (and the marginality of validity). As a matter of fact, the validity of the additional moment conditions used in the levels equations is not rejected when both $\triangle L O A N_{i, t-1}$ and $\triangle D E F_{i, t-1}$ are dropped from the instrument set (the p-values for difference-Sargan tests are .211 and .239 in the default and interest rate equations, respectively). We therefore decided to err on the conservative side and excluded them from the instrument set of both equations in the estimations that follow. 


\subsection{Empirical Results}

The results to be reported are based on the one-step GMM estimators. ${ }^{25}$ The asymptotic variance matrix for them is more reliable than for the two-step GMM (see, e.g. Blundell and Bond, 1998).

The interest rate estimation results are presented in Table 4. Comparing first the coefficients of the lagged dependent variable, we observe that the OLS coefficient (Column (1)) is the largest, the Within coefficient (Column (2)) the smallest, and the GMM estimates (GMM-DIF in Column (3), GMM-SYS in (4)) are in between. ${ }^{26}$ These follow closely the expected pattern, and that reported by Blundell and Bond (1999) in their production function and Monte Carlo studies. Turning to the other parameters, the OLS and Within estimates differ sometimes substantially from the GMM estimates. The GMM-DIF and GMM-SYS estimates are reasonably close to each other, but the latter seem to be more efficient as expected. Concentrating then on the GMM-SYS estimates of our base specification (Column (4)), we find that expected default costs $\left(D E F_{i t}\right)$ do not affect interest rates, but that interest rate costs $\left(I N T D_{i t}\right)$ do have a positive effect. The long-run cost-of-financing elasticity of loan interest rates is .148. The coefficient of loan book size $\left(L O A N_{i t}\right)$ is positive and has a p-value of 0.09 . The summary variable $I N E F F_{i t}$ obtained a negative and significant coefficient. Our variables of most interest, $B R A_{i t}$ and $P E R S_{i t}$, both carry negative and significant coefficients, implying that banks with a larger branch network and more human capital at branch level charge lower interest rates. These results are in line with the information

\footnotetext{
25 The estimates have been produced using Arellano-Bond DPD98, kindly provided by Steve Bond. For reference, we also report OLS and Within Groups estimates. The consistency of these two estimators requires that all explanatory variables are strictly exogenous w.r.t. $v_{j i t}$.

${ }^{26}$ Notice that the number of observations varies over estimation methods as GMM-DIF loses one year (cross-section) due to constructing lags and a second year for first-differencing. GMM-SYS loses only one cross-section.
} 
Table 4.

Interest rate estimation

\begin{tabular}{|c|c|c|c|c|c|c|c|c|}
\hline Variable & $\begin{array}{c}\text { (1) } \\
\text { OLS } \\
\text { (Levels) }\end{array}$ & $\begin{array}{c}(2) \\
\text { WITHIN } \\
\text { GROUPS }\end{array}$ & $\begin{array}{c}(3) \\
\text { GMM- } \\
\text { DIF }\end{array}$ & $\begin{array}{c}(4) \\
\text { GMM- } \\
\text { SYS }\end{array}$ & $\begin{array}{c}(5) \\
\text { GMM- } \\
\text { SYS }\end{array}$ & $\begin{array}{c}(6) \\
\text { GMM- } \\
\text { SYS }\end{array}$ & $\begin{array}{c}(7) \\
\text { GMM- } \\
\text { SYS }\end{array}$ & $\begin{array}{c}(8) \\
\text { GMM- } \\
\text { SYS }\end{array}$ \\
\hline INTL $_{t-1}$ & $\begin{array}{c}.4042 \\
(.0542)\end{array}$ & $\begin{array}{l}-.0857 \\
(.0464)\end{array}$ & $\begin{array}{c}.2838 \\
(.0635)\end{array}$ & $\begin{array}{c}.2620 \\
(0567)\end{array}$ & $\begin{array}{c}.2503 \\
(0544)\end{array}$ & $\begin{array}{c}.2685 \\
(0748)\end{array}$ & $\begin{array}{c}.2662 \\
(.0699)\end{array}$ & $\begin{array}{c}.2639 \\
(.0748)\end{array}$ \\
\hline LOAN & $\begin{array}{l}-.0033 \\
(.0037)\end{array}$ & $\begin{array}{l}-.1292 \\
(.0650)\end{array}$ & $\begin{array}{c}.0763 \\
(.0745)\end{array}$ & $\begin{array}{c}.0323 \\
(.0194)\end{array}$ & $\begin{array}{l}.0215 \\
(.0143)\end{array}$ & $\begin{array}{c}.0263 \\
(.0217)\end{array}$ & $\begin{array}{c}.0261 \\
(.0246)\end{array}$ & $\begin{array}{c}.0171 \\
(.0272)\end{array}$ \\
\hline DEF & $\begin{array}{c}.0030 \\
(.0008)\end{array}$ & $\begin{array}{l}-.0013 \\
(.0010)\end{array}$ & $\begin{array}{c}.0014 \\
(.0030)\end{array}$ & $\begin{array}{c}.0018 \\
(.0027)\end{array}$ & $\begin{array}{c}.0039 \\
(.0025)\end{array}$ & $\begin{array}{c}.0031 \\
(.0031)\end{array}$ & $\begin{array}{c}.0031 \\
(.0032)\end{array}$ & $\begin{array}{c}.0030 \\
(.0031)\end{array}$ \\
\hline INTD & $\begin{array}{c}.0821 \\
(.0219)\end{array}$ & $\begin{array}{l}.1388 \\
(.0431)\end{array}$ & $\begin{array}{l}.1836 \\
(.0775)\end{array}$ & $\begin{array}{l}.1091 \\
(.0420)\end{array}$ & $\begin{array}{l}.1202 \\
(.0670)\end{array}$ & $\begin{array}{l}.1308 \\
(.0604)\end{array}$ & $\begin{array}{l}.1794 \\
(.0588)\end{array}$ & $\begin{array}{c}.1448 \\
(.0633)\end{array}$ \\
\hline INEFF & $\begin{array}{c}-.0805 \\
(.0111)\end{array}$ & $\begin{array}{l}-.1662 \\
(.0215)\end{array}$ & $\begin{array}{l}-.1598 \\
(.0382)\end{array}$ & $\begin{array}{l}-.0893 \\
(.0304)\end{array}$ & $\begin{array}{c}-.0851 \\
(.0331)\end{array}$ & $\begin{array}{c}-.1185 \\
(.0324)\end{array}$ & $\begin{array}{l}-.1220 \\
(.0332)\end{array}$ & $\begin{array}{c}-.1146 \\
(.0310)\end{array}$ \\
\hline BRA & $\begin{array}{l}-.0008 \\
(.0016)\end{array}$ & $\begin{array}{l}-.1117 \\
(.0599)\end{array}$ & $\begin{array}{l}-.1135 \\
(.0736)\end{array}$ & $\begin{array}{l}-.0343 \\
(.0120)\end{array}$ & $\begin{array}{l}-.0307 \\
(.0094)\end{array}$ & $\begin{array}{l}-.0280 \\
(.0110)\end{array}$ & $\begin{array}{c}-.0557 \\
(.0236)\end{array}$ & $\begin{array}{c}-.0286 \\
(.0162)\end{array}$ \\
\hline PERS & $\begin{array}{c}.0052 \\
(.0020)\end{array}$ & $\begin{array}{l}-.1300 \\
(.0626)\end{array}$ & $\begin{array}{l}-.1233 \\
(.0745)\end{array}$ & $\begin{array}{l}-.0426 \\
(.0185)\end{array}$ & $\begin{array}{l}-.0335 \\
(.0145)\end{array}$ & $\begin{array}{c}-.036 \\
(.0196)\end{array}$ & $\begin{array}{l}-.0595 \\
(.0299)\end{array}$ & $\begin{array}{c}-.0329 \\
(.0254)\end{array}$ \\
\hline RDEP & - & - & - & - & $\begin{array}{c}.0427 \\
(.1049)\end{array}$ & - & - & $\begin{array}{l}- \\
-\end{array}$ \\
\hline DENS & - & - & - & - & - & - & $\begin{array}{l}-.0844 \\
(.0384)\end{array}$ & - \\
\hline EDUC & - & - & - & - & - & - & $\begin{array}{c}.0483 \\
(.0199)\end{array}$ & - \\
\hline OWNH & - & - & - & - & - & - & $\begin{array}{c}.0998 \\
(.0790)\end{array}$ & - \\
\hline UE & - & - & - & - & - & - & - & $\begin{array}{c}-.0342 \\
(.0330)\end{array}$ \\
\hline WCAP & - & - & - & - & - & - & - & $\begin{array}{l}-.0011 \\
(.0173)\end{array}$ \\
\hline AGRIC. & - & - & - & - & - & - & - & $\begin{array}{r}-.0123 \\
(.0082) \\
\end{array}$ \\
\hline Nobs. & 1000 & 1000 & 750 & 1000 & 1000 & 750 & 750 & 750 \\
\hline Sargan & - & - & .605 & .448 & .251 & .128 & .130 & .138 \\
\hline $\mathrm{m} 1$ & $\begin{array}{l}-.669 \\
(.503)\end{array}$ & $\begin{array}{l}-1.929 \\
(.054)\end{array}$ & $\begin{array}{l}-5.309 \\
(.000)\end{array}$ & $\begin{array}{l}-5.420 \\
(.000)\end{array}$ & $\begin{array}{l}-5.918 \\
(.000)\end{array}$ & $\begin{array}{l}-5.136 \\
(.000)\end{array}$ & $\begin{array}{l}-5.167 \\
(.000)\end{array}$ & $\begin{array}{l}-5.011 \\
(.000)\end{array}$ \\
\hline $\mathrm{m} 2$ & $\begin{array}{l}1.605 \\
(.108)\end{array}$ & $\begin{array}{l}-.340 \\
(.734)\end{array}$ & $\begin{array}{l}.641 \\
(.521)\end{array}$ & $\begin{array}{l}.500 \\
(.617)\end{array}$ & $\begin{array}{l}.393 \\
(.695)\end{array}$ & - & - & - \\
\hline Wald1 & $\begin{array}{c}360.227 \\
(.000)\end{array}$ & $\begin{array}{l}76.242 \\
(.000)\end{array}$ & $\begin{array}{c}52.771 \\
(.000)\end{array}$ & $\begin{array}{c}38.080 \\
(.000)\end{array}$ & $\begin{array}{c}43.598 \\
(.000)\end{array}$ & $\begin{array}{l}49.195 \\
(.000)\end{array}$ & $\begin{array}{c}51.680 \\
(.000)\end{array}$ & $\begin{array}{c}54.679 \\
(.000)\end{array}$ \\
\hline Wald2 & $\begin{array}{c}589.97 \\
(.000)\end{array}$ & $\begin{array}{c}198.505 \\
(.000)\end{array}$ & $\begin{array}{c}182.918 \\
(.000)\end{array}$ & $\begin{array}{c}410.077 \\
(.000)\end{array}$ & $\begin{array}{c}435.767 \\
(.000)\end{array}$ & $\begin{array}{c}27.103 \\
(.000)\end{array}$ & $\begin{array}{c}27.607 \\
(.000)\end{array}$ & $\begin{array}{c}22.580 \\
(.000)\end{array}$ \\
\hline Wald3 & - & - & - & $\begin{array}{l}8.141 \\
(.017) \\
\end{array}$ & $\begin{array}{c}10.590 \\
(.005) \\
\end{array}$ & $\begin{array}{l}6.620 \\
(.037) \\
\end{array}$ & $\begin{array}{l}5.716 \\
(.057) \\
\end{array}$ & $\begin{array}{l}3.496 \\
(.174) \\
\end{array}$ \\
\hline \multicolumn{9}{|c|}{$\begin{array}{l}\text { NOTES: The GMM-estimates are all one-step. Numbers reported are coefficient and asymptotic } \\
\text { standard errors (s.e.). Reported standard errors are robust to general cross-section and time-series } \\
\text { heteroskedasticity. Nobs is the number of useable observations. All estimations include time dum- } \\
\text { mies. } \\
- \text { Sargan is a test of the overidentifying restrictions for the GMM estimators. Reported numbers are } \\
\text { p-values. } \\
-\mathrm{m} 1 \text { and } \mathrm{m} 2 \text { are tests for } 1^{\text {st }} \text { and } 2^{\text {nd }} \text { order autocorrelation in the first differenced residuals (except } \\
\text { for OLS and Within estimations, in which the tests are for levels residuals); they are asymptotically } \\
\text { distributed N( } 0,1) \text {; (p-values) } \\
- \text { Wald } 1=\text { a Wald test of joint significance of explanatory variables (p-value) } \\
- \text { Wald } 2=\text { a Wald test of joint significance of time dummies (p-value) } \\
- \text { Wald } 3=\text { a Wald test of joint significance of BRA and PERS terms (p-value) }\end{array}$} \\
\hline
\end{tabular}


acquisition model (and the empire-building hypothesis), and reject the market power model. $^{27}$ The estimated elasticities for $B R A_{i t}$ and $P E R S_{i t}$ are small. This indicates that the costs of information acquisition in terms of having to offer lower interest rates to attract those customers the bank has identified as 'good' are low.

Turning to the test statistics, the first differenced residuals display first order auto-correlation as expected, and no second order auto-correlation. The Sargan tests do not reject the overidentifying restrictions in GMM-DIF or GMM-SYS estimations. A Wald statistic testing the joint significance of $B R A_{i t}$ and $P E R S_{i t}$ rejects the Null of them not being jointly different from zero.

We have conducted a number of robustness tests. Firstly, as the time period covered by our data starts with a recession and ends with strong growth, we tested for stability of our coefficients over time. This was done by introducing an indicator variable for the years 95-96 (those with positive GDP growth), and interacted it with other variables. We could not reject the Null that the coefficients are stable over time (p-value: .137). Secondly, as the banks differ substantially in size, we tested whether our coefficients for central variables, i.e., $B R A_{i t}, P E R S_{i t}$, $I N T L_{i, t-1}$ and $D E F_{i t}$, are sensitive to the size of the banks. We introduced an indicator variable that took the value unity if the sum of $L O A N_{i t}$ and interbank lending (e.g. total loans) was above mean (and as an alternative, median) and zero otherwise, and interacted it with the aforementioned variables. Again, the Null could not be rejected at conventional levels (p-value: .270). Thirdly, earlier literature (Fama, 1985 and Vale, 1993 in particular) has suggested that banks can use de-

\footnotetext{
${ }^{27}$ It is worth noticing that the Within estimate produces positive and significant coefficients for $B R A$ and PERS (OLS for PERS), which would support the market power hypothesis and reject the information acquisition hypothesis. We have however tested the Null of BRA and PERS being predetermined against the alternative of them being endogenous. Using a difference Sargan test we rejected the Null at 5\% level (p-value was .034). Based on this, the consistency of OLS and Within Groups estimators can be questioned.
} 
posits to monitor the cash flow of their loan customers, and thereby gain information on the riskiness of loans. We tested whether this affects loan interest rates by including the variable $R D E P_{i t}$, defined as the ratio of deposits made by customers to the sum of customer deposits and interbank borrowing. Treating $R D E P_{i t}$ as endogenous, we find that it has no effect on loan interest rates of banks.

The estimates using the whole panel do not have exogenous variables, as market characteristics are currently only available up to 1995 . In Column (6) we therefore reproduce the estimation of Column (4) (GMM-SYS), using 92-95 data. As the column reveals, our results are robust to excluding 1996, a year with a strongly growing economy. In Columns (7) and (8) we add different market characteristics into the model. In these exercises, the market level variables are treated as strictly exogenous (and they are only used to instrument themselves). Adding a group of demographic variables (population density $\left(D E N S_{i t}\right.$, see Table 3 for definitions), education $\left(E D U C_{i t}\right)$ and home ownership $\left.\left(O W N H_{i t}\right)\right)$ leads to higher absolute values for $B R A_{i t}$ and $P E R S_{i t}$ coefficients. Two of the three market characteristics obtain statistically significant coefficients. Adding controls for unemployment $\left(U E_{i t}\right)$, wealth per capita $\left(W C A P_{i t}\right)$ and agriculture $\left(A G R I C_{i t}\right)$ drives $P E R S_{i t}$ into insignificance, and $B R A_{i t}$ is only marginally significant. However, none of these three controls carries a statistically significant coefficient. We conclude that our results on the negative effects of branch network density and bank human capital on loan interest rates are robust.

Turning then to the results for the default equation in Table 5 (the column order is as in Table 4), we find that the coefficients of the lagged dependent variable generated by different estimation methods follow the expected pattern, with the GMM-SYS estimate being .19. Again concentrating on the GMM-SYS estimates (base specification in Column (4)) we find first of all that an increase in the 
Table 5.

Default cost estimation

\begin{tabular}{|c|c|c|c|c|c|c|c|c|}
\hline Variable & $\begin{array}{c}\text { (1) } \\
\text { OLS } \\
\text { (Levels) }\end{array}$ & $\begin{array}{c}(2) \\
\text { WITHIN } \\
\text { GROUPS }\end{array}$ & $\begin{array}{c}\text { (3) } \\
\text { GMM- } \\
\text { DIF }\end{array}$ & $\begin{array}{c}\text { (4) } \\
\text { GMM- } \\
\text { SYS }\end{array}$ & $\begin{array}{c}(5) \\
\text { GMM- } \\
\text { SYS }\end{array}$ & $\begin{array}{c}\text { (6) } \\
\text { GMM- } \\
\text { SYS }\end{array}$ & $\begin{array}{c}(7) \\
\text { GMM- } \\
\text { SYS }\end{array}$ & $\begin{array}{c}(8) \\
\text { GMM- } \\
\text { SYS }\end{array}$ \\
\hline $\mathrm{DEF}_{\mathrm{t}-1}$ & $\begin{array}{c}.3597 \\
(.0432)\end{array}$ & $\begin{array}{l}-.0676 \\
(.0415)\end{array}$ & $\begin{array}{c}.2062 \\
(.0645)\end{array}$ & $\begin{array}{c}.1874 \\
(.0586)\end{array}$ & $\begin{array}{c}.1864 \\
(.0590)\end{array}$ & $\begin{array}{c}.1691 \\
(.0759)\end{array}$ & $\begin{array}{c}.1805 \\
(.0777)\end{array}$ & $\begin{array}{c}.1744 \\
(.0766)\end{array}$ \\
\hline LOAN & $\begin{array}{c}.8075 \\
(.1505)\end{array}$ & $\begin{array}{c}.9424 \\
(1.4133)\end{array}$ & $\begin{array}{c}1.7024 \\
(3.7771)\end{array}$ & $\begin{array}{l}3.7453 \\
(.7300)\end{array}$ & $\begin{array}{l}2.6333 \\
(.6069)\end{array}$ & $\begin{array}{l}2.7800 \\
(.6899)\end{array}$ & $\begin{array}{l}3.2025 \\
(.8311)\end{array}$ & $\begin{array}{l}2.7991 \\
(.8369)\end{array}$ \\
\hline INTL & $\begin{array}{c}4.8798 \\
(1.8183)\end{array}$ & $\begin{array}{c}3.8350 \\
(2.5887)\end{array}$ & $\begin{array}{c}8.7792 \\
(3.0866)\end{array}$ & $\begin{array}{c}6.6033 \\
(2.8105)\end{array}$ & $\begin{array}{c}4.3394 \\
(2.7927)\end{array}$ & $\begin{array}{c}5.3234 \\
(2.8791)\end{array}$ & $\begin{array}{c}5.4560 \\
(2.9362)\end{array}$ & $\begin{array}{c}5.3366 \\
(3.0813)\end{array}$ \\
\hline INEFF & $\begin{array}{l}1.7917 \\
(.3763)\end{array}$ & $\begin{array}{l}-1.2155 \\
(0.8235)\end{array}$ & $\begin{array}{c}.1381 \\
(1.1478)\end{array}$ & $\begin{array}{c}-.0133 \\
(1.1657)\end{array}$ & $\begin{array}{l}-1.0459 \\
(1.1714)\end{array}$ & $\begin{array}{c}-.6972 \\
(1.3052)\end{array}$ & $\begin{array}{c}-.2317 \\
(1.2875)\end{array}$ & $\begin{array}{c}-.1519 \\
(1.3086)\end{array}$ \\
\hline BRA & $\begin{array}{l}-.0816 \\
(.0871)\end{array}$ & $\begin{array}{c}-.4618 \\
(1.6473)\end{array}$ & $\begin{array}{c}-8.3117 \\
(4.3744)\end{array}$ & $\begin{array}{r}-1.7526 \\
(.6883)\end{array}$ & $\begin{array}{l}-.9105 \\
(.4830)\end{array}$ & $\begin{array}{l}-.9589 \\
(.5282)\end{array}$ & $\begin{array}{l}-1.5315 \\
(.9922)\end{array}$ & $\begin{array}{l}-.5968 \\
(.6700)\end{array}$ \\
\hline PERS & $\begin{array}{l}-.3318 \\
(.1117)\end{array}$ & $\begin{array}{c}-.9108 \\
(1.6092)\end{array}$ & $\begin{array}{c}-10.1814 \\
(4.4300)\end{array}$ & $\begin{array}{c}-3.3185 \\
(.9000)\end{array}$ & $\begin{array}{r}-2.3859 \\
(.7332)\end{array}$ & $\begin{array}{c}-2.4946 \\
(.8032)\end{array}$ & $\begin{array}{l}-3.1466 \\
(1.2863)\end{array}$ & $\begin{array}{c}-2.0503 \\
(.9521)\end{array}$ \\
\hline SBFD & - & - & - & $\begin{array}{c}-1.2651 \\
(.5088)\end{array}$ & $\begin{array}{c}-1.1486 \\
(.4733)\end{array}$ & $\begin{array}{c}-1.1676 \\
(.5202)\end{array}$ & $\begin{array}{c}-1.2964 \\
(.5965)\end{array}$ & $\begin{array}{l}-1.0320 \\
(0.4988)\end{array}$ \\
\hline RDEP & - & - & - & - & $\begin{array}{l}-8.3351 \\
(3.2574)\end{array}$ & $\begin{array}{l}-8.6013 \\
(4.1885)\end{array}$ & $\begin{array}{l}-7.4997 \\
(3.8598)\end{array}$ & $\begin{array}{l}-7.3036 \\
(4.4642)\end{array}$ \\
\hline DENS & - & - & - & - & - & - & $\begin{array}{c}-2.8371 \\
(1.6670)\end{array}$ & - \\
\hline EDUC & - & - & - & - & - & - & $\begin{array}{c}.9744 \\
(.9063)\end{array}$ & - \\
\hline OWNH & - & - & - & - & - & - & $\begin{array}{c}7.0733 \\
(3.3794)\end{array}$ & - \\
\hline UE & - & - & - & - & - & - & - & $\begin{array}{c}.1693 \\
(1.3596)\end{array}$ \\
\hline WCAP & - & - & - & - & - & - & - & $\begin{array}{l}1.5145 \\
(.8060)\end{array}$ \\
\hline AGRIC. & - & - & - & - & - & - & - & $\begin{array}{c}.4435 \\
(.3559)\end{array}$ \\
\hline Nobs. & 1000 & 1000 & 750 & 1000 & 1000 & 750 & 750 & 750 \\
\hline Sargan & - & - & .281 & .195 & .278 & .556 & .479 & .430 \\
\hline $\mathrm{m} 1$ & $\begin{array}{c}.467 \\
(.640)\end{array}$ & $\begin{array}{c}-5.016 \\
(.000)\end{array}$ & $\begin{array}{c}-5.302 \\
(.000)\end{array}$ & $\begin{array}{r}-5.053 \\
(.000)\end{array}$ & $\begin{array}{c}-4.963 \\
(.000)\end{array}$ & $\begin{array}{c}-3.877 \\
(.000)\end{array}$ & $\begin{array}{r}-3.903 \\
(.000)\end{array}$ & $\begin{array}{r}-3.897 \\
(.000)\end{array}$ \\
\hline $\mathrm{m} 2$ & $\begin{array}{c}.801 \\
(.423)\end{array}$ & $\begin{array}{l}-1.539 \\
(.124)\end{array}$ & $\begin{array}{l}-.393 \\
(.695)\end{array}$ & $\begin{array}{l}.270 \\
(.788)\end{array}$ & $\begin{array}{l}.418 \\
(.676)\end{array}$ & - & - & - \\
\hline Wald1 & $\begin{array}{c}342.643 \\
(.000)\end{array}$ & $\begin{array}{l}12.826 \\
(.046)\end{array}$ & $\begin{array}{c}21.206 \\
(.002)\end{array}$ & $\begin{array}{c}54.881 \\
(.000)\end{array}$ & $\begin{array}{c}84.384 \\
(.000)\end{array}$ & $\begin{array}{l}77.291 \\
(.000)\end{array}$ & $\begin{array}{l}75.018 \\
(.000)\end{array}$ & $\begin{array}{c}98.562 \\
(.000)\end{array}$ \\
\hline Wald2 & $\begin{array}{c}10.488 \\
(.015)\end{array}$ & $\begin{array}{l}8.433 \\
(.038)\end{array}$ & $\begin{array}{l}9.850 \\
(.020)\end{array}$ & $\begin{array}{l}7.144 \\
(.067)\end{array}$ & $\begin{array}{l}9.987 \\
(.019)\end{array}$ & $\begin{array}{c}13.164 \\
(.001)\end{array}$ & $\begin{array}{c}18.475 \\
(.000)\end{array}$ & $\begin{array}{l}4.558 \\
(.102)\end{array}$ \\
\hline Wald3 & - & - & $\begin{array}{l}9.463 \\
(.009)\end{array}$ & $\begin{array}{c}13.968 \\
(.001)\end{array}$ & $\begin{array}{l}10.827 \\
(.004)\end{array}$ & $\begin{array}{l}9.872 \\
(.007)\end{array}$ & $\begin{array}{l}7.760 \\
(.021)\end{array}$ & $\begin{array}{l}6.850 \\
(.033)\end{array}$ \\
\hline
\end{tabular}


loan interest rate $\left(I N T L_{i t}\right)$ increases the amount of defaults significantly (the longrun interest rate elasticity of defaults is 8.126). This is in line with our (and others') theoretical models. Even after controlling for this effect, banks with larger loan books have larger relative default costs. This could reflect the specificity of our sample period and a situation where small banks chose their customers more carefully. It is well known that banks operating in the larger cities made larger relative credit losses during the banking crisis than banks operating in small(er) municipalities. However, it is also possible that the result is not period specific. It implies that conditional on the level of sunk investments, a larger loan book (implying a higher number of granted loans) leads to larger default costs. Decreasing returns to scale in the information acquisition technology would lead to the result. The summary variable $I N E F F_{i t}$ has no effect on default costs, but we find that banks to which former savings banks' branches have been merged have lower credit losses. A possible explanation for this is that only healthier (the dismantling of SBF took place during 1992-1993, in the midst of the banking crisis) cooperative banks were willing (alternatively, were allowed to by the government) to take on former savings banks' branches. Also, as a part of the dismantling of SBF, its worst loans were transferred into a government run 'bad' bank, and the banks buying parts of SBF only took on their books loans deemed healthy. Most significantly, however, we find that both variables capturing sunk costs have significant negative effects on default costs, supporting the information acquisition hypothesis. The estimated long-run elasticities are -2.15 for branch density and -4.08 for personnel costs. These results reject both the market power model (and also the managerial rents-hypotheses).

Turning briefly to the test statistics, they display similar patterns as in the interest rate equation. In particular, the Sargan tests do not reject the overidenti- 
fying restrictions in GMM-DIF or GMM-SYS estimations and a Wald statistic rejects the Null of $B R A_{i t}$ and $P E R S_{i t}$ being not jointly different from zero.

We conducted the same robustness tests as with the interest rate equation, with similar results bar one exception. ${ }^{28}$ The $R D E P_{i t}$ variable (see Column (5)) obtained a negative and significant coefficient (-8.34) when added to the specification and treated as being endogenous and correlated in levels with the bankspecific effects. This provides evidence that banks can indeed use information obtained from monitoring their customers' cash flows to decrease their credit losses. Concurrently and independently, Mester et al. (1998) have obtained a similar result using data on U.S. checking accounts. Adding $R D E P_{i t}$ reduces the absolute size of the $B R A_{i t}$ and $P E R S_{i t}$ coefficients to -.91 and -2.38 , respectively. They do remain statistically significant, however.

Excluding the 1996 data does not materially affect the results (Column (6)). Adding exogenous control variables to the specification changes somewhat the $B R A_{i t}$ and $P E R S_{i t}$ coefficients; however, only two of the six exogenous regressors $\left(O W N H_{i t}\right.$ and $A G R I C_{i t}$ respectively in Columns (7) and (8)) obtain statistically significant coefficients. Adding $D E N S_{i t}, E D U C_{i t}$ and $O W N H_{i t}$ renders the $B R A_{i t}$ coefficient significant at only $12 \%$ level; $B R A_{i t}$ and $P E R S_{i t}$ are still jointly significant. Adding $U E_{i t}, W C A P_{i t}$ and $A G R I C_{i t}$ results in a insignificant $B R A_{i t}$ coefficient, but $B R A_{i t}$ and $P E R S_{i t}$ are still jointly significant.

As a last robustness check, we tested whether future default costs (above and beyond one year) are affected by current values of $B R A_{i t}$ and $P E R S_{i t}$. The aim is to control for the definition of $D E F_{i t}$. It is calculated using the net charge-offs

\footnotetext{
${ }^{28}$ When using the median of $\left(L O A N_{i t}+\right.$ interbank loans) as the size criterion (instead of the mean of $\left(L O A N_{i t}+\right.$ interbank loans) criterion), we could not reject the Null that large banks have different $B R A_{i t}, P E R S_{i t}, D E F_{i, t-1}$ and $I N T L_{i t}$ coefficients than small banks. This was however entirely driven by the coefficient of the interaction variable obtained by $D E F_{i, t-1}$ times the dummy (the other interactions carried insignificant coefficients), and we therefore do not report these results.
} 
(default costs) of the current period, in line with our theoretical model. However, in reality, banks incur default costs from loans made in previous periods as it takes time before loan risks realize and before loans are written off. The assumption in our monitoring model is that sunk costs are investments to improve bank's ability to ex ante identify projects with small liquidation costs and/or high resale value. It could be that sunk costs are instead used to improve banks' interim and ex post monitoring ability (costly state verification). To some extent we control for this in all estimations by using the number of branches at the beginning of the year when computing $B R A_{i t}$. One could however argue that if only current levels of $B R A_{i t}$ and $P E R S_{i t}$ (as defined) affected $D E F_{i t}$ negatively, it would not be clear which of the two phenomena is the one generating the results. Finding that lagged values of $B R A$ and $P E R S$ variables affect current values of $D E F_{\text {it }}$ negatively would provide additional support for our assumption of ex ante monitoring.

The results of the estimations are reported in Table 6, where we have used the GMM-SYS estimator and the same instruments as above. The first Column reproduces our base specification on 1992-96 data. Column (2) replaces the current values of $B R A_{i t}$ and $P E R S_{i t}$ with once lagged values $\left(B R A_{i, t-1}\right.$ and $\left.P E R S_{i, t-1}\right)$. In Column (3), BRA $A_{i t}$ and $P E R S_{i t}$ have been lagged two years, and Column (4) reports a specification with both current and once lagged values of $B R A$ and $P E R S$ variables. The idea behind including them is that in any given year, $D E F_{i t}$ consists of defaulted loans granted in different years. As the relationship between these explanatory variables and $D E F_{i t}$ could well be nonlinear, and because the current and lagged levels of $B R A_{i t}$ and $P E R S_{i t}$ are relatively strongly (auto)correlated, we 
Table 6.

Default cost estimations (1992-1996) with lagged BRA and PERS

\begin{tabular}{|c|c|c|c|c|c|}
\hline Variable & $(1)$ & $(2)$ & (3) & (4) & $(5)$ \\
\hline \multirow[t]{2}{*}{$\mathrm{DEF}_{\mathrm{t}-1}$} & .1874 & .1926 & .278370 & .1937 & .1885 \\
\hline & $(.0586)$ & $(.0595)$ & $(.0849)$ & $(.0567)$ & $(.0568)$ \\
\hline \multirow[t]{2}{*}{ LOAN } & 3.7453 & 1.5720 & 1.4900 & 3.5924 & 3.6233 \\
\hline & $(.7300)$ & $(.5476)$ & $(.5252)$ & $(.7379)$ & $(.6539)$ \\
\hline \multirow[t]{2}{*}{ INTL } & 6.6033 & 4.1526 & 6.7225 & 6.9403 & 6.5391 \\
\hline & (2.8104) & $(2.5040)$ & (4.0099) & $(2.7583)$ & (2.6596) \\
\hline \multirow[t]{2}{*}{ INEFF } & -.0132 & 3885 & -.6718 & .2371 & .2304 \\
\hline & (1.1656) & $(0.9628)$ & (1.3835) & (1.1142) & (1.0641) \\
\hline \multirow[t]{2}{*}{ BRA } & -1.7526 & - & - & -2.4266 & -.9591 \\
\hline & $(.6882)$ & & & (1.0670) & $(.3745)$ \\
\hline \multirow[t]{2}{*}{ PERS } & -3.3185 & - & - & -4.0592 & -2.7016 \\
\hline & $(.9001)$ & & & (1.2874) & $(.6555)$ \\
\hline \multirow[t]{2}{*}{ BRA $_{t-1}$} & - & -1.1159 & - & 1.1981 & - \\
\hline & & $(.6984)$ & & (1.2122) & \\
\hline \multirow[t]{2}{*}{ PERS $_{\mathrm{t}-1}$} & - & -.6880 & - & 1.0709 & - \\
\hline & & (.6869) & & (1.1101) & \\
\hline \multirow[t]{2}{*}{$\mathrm{BRA}_{\mathrm{t}-2}$} & - & - & -1.4877 & - & - \\
\hline & & & $(.6666)$ & & \\
\hline \multirow[t]{2}{*}{ PERS $_{\mathrm{t}-2}$} & - & - & -.9144 & - & - \\
\hline & & & $(.6795)$ & & \\
\hline$\left(\mathrm{BRA}_{\mathrm{t}-1}\right)^{2}$ & - & - & - & - & $\begin{array}{c}.0031 \\
(.0214)\end{array}$ \\
\hline$\left(\operatorname{PERS}_{\mathrm{t}-1}\right)^{2}$ & - & - & - & - & $\begin{array}{c}-.305673 \\
(.1158)\end{array}$ \\
\hline Nobs. & 1000 & 1000 & 750 & 1000 & 1000 \\
\hline Sargan & .195 & .057 & .241 & .142 & .186 \\
\hline \multirow[t]{2}{*}{$\mathrm{m} 1$} & -5.053 & -5.116 & -3.957 & -5.063 & -5.248 \\
\hline & $(.000)$ & $(.000)$ & $(.000)$ & $(.000)$ & $(.000)$ \\
\hline \multirow[t]{2}{*}{$\mathrm{m} 2$} & .270 & .191 & - & .254 & .192 \\
\hline & $(.788)$ & $(.849)$ & & $(.800)$ & $(.848)$ \\
\hline \multirow[t]{2}{*}{ Wald1 } & 54.881 & 65.363 & 52.607 & 64.871 & 96.906 \\
\hline & $(.000)$ & $(.000)$ & $(.000)$ & $(.000)$ & $(.000)$ \\
\hline \multirow[t]{2}{*}{ Wald2 } & 7.1438 & 11.441 & 2.679 & 5.578 & 11.532 \\
\hline & $(.067)$ & $(.010)$ & $(.262)$ & $(.134)$ & $(.009)$ \\
\hline \multirow[t]{2}{*}{ Wald3 } & -13.968 & 4.016 & 8.252 & 15.054 & 18.551 \\
\hline & $(.001)$ & $(.138)$ & $(.016)$ & $(.005)$ & $(.001)$ \\
\hline
\end{tabular}


experimented with including the squared (logs of) lagged BRA and PERS (Column (5)).

Using the once lagged values we find that both $B R A_{i, t-1}$ and $P E R S_{i, t-1}$ carry imprecisely measured negative coefficients. The p-value of a test of joint significance is 0.138 . Lagging the variables twice results in negative coefficients; that of $B R A_{i, t-2}$ is significant, and they are also jointly significant. In Column (4) we find that current values of $B R A_{i t}$ and $P E R S_{i t}$ obtain negative and significant, and lagged values positive and insignificant coefficients. Column (5) shows that both current values and the lagged squared values of the PERS variable carry negative and significant coefficient. The coefficient of the lagged squared $B R A$ variable is positive but insignificant. Though not as strong as those reported in Table 5, these results support the assumption of out theoretical model that sunk costs contribute to the ex ante information acquisition ability of banks.

\section{Conclusions}

The main objective of this paper was to shed light on whether banks use their sunk investments for information acquisition, or for obtaining market power. Our theoretical model allows us to study such investments within a common modeling framework. Different types of sunk investments have very different empirical implications. Our main interest was on sunk investments's effect on banks' lending quality (i.e, on the riskiness of the bank's loan portfolio) and the interest rate charged by the bank. Our theoretical prediction is that information acquisition leads to a lower amount of defaults and to a lower interest rate margin. Market power investments, in contrast, have no direct effect on default costs (an indirect positive effect through the interest rate), and lead to higher interest rates. 
We tested these theories on panel data covering 250 Finnish local banks and five years. The fact that these banks operate in non-overlapping regional markets means that the equilibrium level of investments varies over banks, thus allowing us to identify the effects of sunk investments on bank performance. The nonrandom nature of the sample, and the shared features and institutions of the cooperative banks allowed us to assume that they use their fixed investments for the same purpose. They also simultaneously enabled us to avoid the problem (predicted by our theory) of having both investing and non-investing banks in our sample.

We found persistence in both loan interest rates and default costs. Loan interest rates are an increasing function of deposit interest rates. Unsurprisingly, higher interest rates increase default costs. Banks with larger loan books have higher (relative) default costs. We found that banks' investments in both branch network density and human capital (personnel) contribute to the information acquisition ability of banks as both loan interest rates and default costs are decreasing in these variables. These findings thus lead us to reject the market power hypothesis (and also the most obvious versions of managerial rent seeking explanations). In addition, we find evidence supporting the hypothesis (Fama, 1985) that banks use deposits to monitor the cash flow of customers, and are thereby able to decrease the amount of credit losses. These results were robust to a number of experiments. In particular, we found that lagged values of branch network density and personnel have a similar effect on current default costs. These findings support the assumption of our theoretical model that banks use sunk investments for ex ante information acquisition, rather than for ex post monitoring. 


\section{References}

Angbazo, L., 1997, Commercial bank net interest margins, default risk, interest-rate risk, and offbalance sheet banking, Journal of Banking and Finance 21, pp. 55-87.

Arellano, M. and Bond, S., 1991, Some tests of specification for panel data: Monte Carlo evidence and an application to employment equations, Review of Economic Studies 58, pp. 277-297.

Arellano, M. and Bover, O., 1995, Another look at the instrumental variable estimation of errorcomponent models, Journal of Econometrics 68, pp. 29-51.

Baltagi, B., 1981, Simultaneous equations with error components, Journal of Econometrics 17, pp. 21-49.

Broecker, T., 1990, Credit-worthiness tests and interbank competition, Econometrica 58, pp. 429452.

Blundell, R., and Bond, S., 1998, Initial conditions and moment restrictions in dynamic panel data models, Journal of Econometrics 87, pp. 115-143.

Blundell, R., and Bond, S., 1999, GMM estimation with persistent panel data: an application to production functions, The Institute for Fiscal Studies, Working Paper, W99/4.

Bond, S., and Meghir, C., 1994, Dynamic investment models and the firm's financial policy, $R e$ view of Economic Studies 61, pp. 197-222.

Chan, Y-S., and Thakor, A. V., 1987, Collateral and competitive equilibria with moral hazard and private information, Journal of Finance 42, pp. 345-363.

Cosimano, T. F., and B. McDonald, 1998, What's different among banks?, Journal of Monetary Economics 41, pp. 57-70.

Davis, E. P., 1995, Debt, Financial Fragility and Systemic Risk (Revised and Expanded Edition), Oxford University Press, Oxford.

Degryse, H., 1996, On the interaction between vertical and horizontal product differentiation: An application to banking, Journal of Industrial Economics 44, pp. 169-186.

Fama, E., 1985, What's different about banks?, Journal of Monetary Economics 15, pp. 29-39.

Freixas, X., and Rochet, J-C., 1997, The microeconomics of banking, MIT Press, Cambridge, MA.

Greenwald, and Stiglitz, J., 1993, Financial Market Imperfections and Business Cycles, Quarterly Journal of Economics 108, pp. 77-114.

Holmström, B., and J. Tirole, 1997, Financial intermediation, loanable funds, and the real sector, Quarterly Journal of Economics 112, pp. 663-691.

James, C., 1987, Some evidence on the uniqueness of bank loans, Journal of Financial Economics 19, pp. 217-235.

Klein, M. A., 1971, A theory of the banking firm, Journal of Money, Credit and Banking 3, pp. 205-218. 
Koskenkylä, H., and Vesala, J., 1994, Finnish deposit banks 1980-1993: Years of Rapid Growth and Crisis, Bank of Finland, Discussion Papers, 16/94.

Leland, H. E., and D. Pyle, 1977, Informational asymmetries, financial structure and financial intermediation, Journal of Finance 32, pp. 371-387.

Mester, L. J., Nakamura, L. I., and Renault, M., 1998, Checking Accounts and Bank Monitoring, Federal Reserve Bank of Philadelphia, Working Paper, No. 98-25.

Molyneux, P., Lloyd-Williams, D. M., and Thornton, J., 1994, Competitive conditions in European banking, Journal of Banking and Finance 18, pp. 445-459.

Nyberg, P., and Vihriälä, V., 1994, The Finnish banking crisis and its handling, Bank of Finland, Discussion Paper, 7/94.

Petersen, M., and Rajan, R., 1994, The benefits of lending relationships: Evidence from small business data, Journal of Finance 49, pp. 3-37.

Rousseau, P. L., 1998, The permanent effects of financial innovation on financial depth: Theory and US historical evidence from unobservable components models, Journal of Monetary Economics 42, pp. 387-425.

Shaked, A., and Sutton, J., 1982, Relaxing price competition through product differentiation, $R e$ view of Economic Studies 49, pp. 3-13.

Shaked, A., and Sutton, J., 1983, Natural oligopolies, Econometrica 51, pp. 1469-1484.

Sharpe, S. A., 1990, Asymmetric information, bank lending and implicit contracts: A stylized model of customer relationships, Journal of Finance 45, pp. 1069-1087.

Spiller, P. T., and Favaro E., 1984, The effects of entry regulation on oligopolistic competition: The Uruguayan banking sector, Rand Journal of Economics 15, pp. 244-254.

Stiglitz, J. E., 1985, Credit markets and the control of capital, Journal of Money, Credit and Banking 17, pp. 133-152.

Toivanen, O., 1998, Adverse selection and testing: application to and evidence from insurance markets, Helsinki School of Economics, mimeo.

Toivanen, O., and Cressy, R., 1998, Is there adverse selection in the credit market?, Helsinki School of Economics and University of Warwick, mimeo.

Vale, B., 1993, The dual role of demand deposits under asymmetric information, Scandinavian Journal of Economics 95, pp. 77-95.

Vihriälä, V., 1997, Banks and the Finnish credit cycle 1986-1995, Bank of Finland Studies, E:7.

Wang, C., and Williamson, S., 1998, Debt contracts and financial intermediation with costly screening, Canadian Journal of Economics 31, pp. 573-595.

Williamson, S., 1986, Costly monitoring, financial intermediation, and equilibrium credit rationing, Journal of Monetary Economics 18, pp. 159-179.

Williamson, S., 1987, Costly monitoring, loan contracts, and equilibrium credit rationing, Quarterly Journal of Economics 102, pp. 135-145. 


\section{Appendix 1.}

PROOF OF PROPOSITION 1, Part (a): To begin with, note that the no-crosssubstitution assumption implies that $R_{M, p} \geq R_{v(p)}^{0}$ holds for $p \in\{G, B\}$. Then, for a sub-game perfect solution, consider the follower. Whenever feasible, the nonmonitoring follower will optimally undercut either both offers or the higher offer of the leader depending on which action yields higher profits. If this strategy is not feasible, the follower tries at least to match one of the offers so as to split the entrepreneurs in this category just to remain in business. We can now turn to the leader's strategy:

Claim 1. The monitoring leader cannot earn strictly positive expected profits from both entrepreneur categories in equilibrium.

To prove the claim, suppose for contradiction that the opposite holds. Then it must be the case that $R_{M, p}>R_{v(p)}^{0}$ holds for $p \in\{G, B\}$. But for any such interest rate pair, the follower will optimally undercut either both offers or the higher offer depending on which action yields higher profits, and capture all the entrepreneurs or those to whom the higher rate was quoted, thus contradicting the assumption. Only when $R_{M, G} \leq R_{v(G B)}^{0}$ and $R_{M, B}=R_{v(B)}^{0}$, there exists no such strictly profitable undercutting opportunity for the non-monitoring follower. To see this, note that should the follower undercut either loan rate, it would make non-positive expected profits. In this case, however, zero-profits are earned by the leader from the customers labeled bad, which again contradicts the assumption. Claim 1 hence holds.

The implication of the above is that the optimal strategy of the monitoring leader involves "bribery pricing" so as to maximize its profits from the borrower category from which it (potentially) can earn strictly positive profits. Given the 
under-cutting option of the follower, the leader can compute and announce an indifference rate at which the follower is indifferent between trying to become the sole financier of $G B$ (by undercutting both of the offers of the leader), and financing solely those entrepreneurs to whom the leader quotes a higher interest rate. Consider a strategy where such an indifference rate, $R_{p}^{\text {ind }}$, is quoted for category $p \in\{G, B\}$ and where the other category $p^{\prime} \neq p$ is priced out by quoting an interest rate that is strictly higher than $R^{*}$ (i.e., the monopoly rate). If such an interest rate pair was observed by the follower, its optimal response would be to quote $R_{N M}=R^{*}$ since (by construction) it has no profit incentive to undercut the offer made by the leader for $p$. The follower would end up financing category $p^{\prime}$ at rate $R^{*}$. This implies that if the category to which no interest rate is quoted by the leader is $B$ (i.e. if $p^{\prime}=B$ ), the indifference rate, $R_{G}^{\text {ind }}$ (quoted for the good by the monitoring leader) is found by solving the equation

$$
(E(x)-v(G B))\left(1-\exp \left(-\lambda R_{G}^{\text {ind }}\right)-(1+\rho)=\pi\left(R^{*}, v(B)\right)\right.
$$

where $\pi\left(R^{*}, v(B)\right)=\left(1-G\left(s^{m}\right)\right)\left((E(x)-v(B))\left(1-\exp \left(-\lambda R^{*}\right)\right)-(1+\rho)\right)$.

Alternatively, if $p^{\prime}=G$, the relevant indifference rate, $R_{B}^{\text {ind }}$, is solved from equation

$$
(E(x)-v(G B))\left(1-\exp \left(-\lambda R_{B}^{\text {ind }}\right)-(1+\rho)=\pi\left(R^{*}, v(G)\right)\right.
$$

where $\pi\left(R^{*}, v(G)\right)=G\left(s^{m}\right)\left((E(x)-v(G))\left(1-\exp \left(-\lambda R^{*}\right)\right)-(1+\rho)\right)$. In the above equations, $\pi\left(R^{*}, v(B)\right)$ and $\pi\left(R^{*}, v(G)\right)$ are the expected profits for the follower from cases $p^{\prime}=B$ and $p^{\prime}=G$, respectively. Since banks' expected profits are increasing in the loan interest rate within any given entrepreneur category, in either case the monitoring leader's profit from $p$ are higher the higher is the indifference interest rate at which it provides financing for $p$. The observation that the indif- 
ference interest rates are higher the higher are the expected profits of the follower from cases $p^{\prime}=B$ and $p^{\prime}=G$, allows us to write down

Claim 2. It is optimal for the monitoring leader to price out $p^{\prime}$ as this maximizes the follower's profit from this entrepreneur category and therefore also the associated indifference interest rate that the monitoring bank can charge from $p$.

Note in particular, that if the leader quoted the monopoly interest rate for category $p^{\prime}$, the associated indifference interest rate would be strictly lower than it would be if a marginally higher interest rate were quoted.

Claim 3. The optimal (bribery) pricing by the monitoring leader involves pricing out bad entrepreneurs $\left(p^{\prime}=B\right)$ and quoting the indifference rate defined by equation (1.1) for good entrepreneurs $(p=G)$. The best response by the follower to such an interest rate schedule is to name the monopoly interest rate.

To prove the claim, note that the expected profits for the monitoring leader from the case in which the indifference rate was quoted for good entrepreneurs, i.e., $p=G$, are $\pi\left(R_{G}^{i n d}, v(G)\right)=G\left(s^{m}\right)\left[\frac{(E(x)-v(G)) \pi\left(R^{*}, v(B)\right)+(1+\rho)(v(G B)-v(G))}{E(x)-v(G B)}\right]$

and, from the alternative case $p=B$

$\pi\left(R_{B}^{i n d}, v(B)\right)=\left(1-G\left(s^{m}\right)\right)\left[\frac{(E(x)-v(B)) \pi\left(R^{*}, v(G)\right)+(1+\rho)(v(G B)-v(B))}{E(x)-v(G B)}\right]$

Since $v$ is uniformly distributed, it is easy to verify, firstly, that

$$
v(G)=\frac{1}{2} s^{m}, v(B)=\frac{1}{2}\left(s^{m}+\bar{v}\right), v(G B)=\frac{1}{2} \bar{v} \text { and } G\left(s^{m}\right)=s^{m} / \bar{v} .
$$

and then, secondly, that

$$
\pi\left(R_{G}^{\text {ind }}, v(G)\right)>\pi\left(R_{B}^{\text {ind }}, v(B)\right) \text { for } 0<s^{m}<\bar{v} .
$$

As the best response by the follower to $R_{G}^{\text {ind }}$ is to quote the monopoly rate, claim 3 follows. 
Thus, in equilibrium, the leader ends up financing entrepreneurs it classified good whereas the follower provides financing for entrepreneurs classified bad by the monitoring leader. This completes the proof of part (a) of Proposition 1. QED.

PROOF OF PROPOSITION 1, Part (b): Recall that the no-cross-substitution assumption implies that $R_{M, B} \geq R_{v(B)}^{0}$. We begin by claiming that the nonmonitoring leader cannot announce an interest rate (stricly) below $R_{v(B)}^{0}$. For proof, suppose it did and offered an interest rate marginally below $R_{v(B)}^{0}$. The follower's best response would clearly be to offer exactly the same interest rate for all good entrepreneurs and any rate higher than or equal to $R_{v(B)}^{0}$ to those it labeled bad. From this and Assumption A3 it follows that all the good entrepreneurs (in category $G$ ) would prefer the monitoring follower to the leader. This means that at any rate below $R_{v(B)}^{0}$ the leader finances only those allocated in $B$ by the monitoring bank at an interest rate implying negative expected profits for it. Hence the claim must hold in equilibrium.

Note that if the non-monitoring leader tried to set an interest rate higher than $R_{v(B)}^{0}$ it would provide an incentive for the follower to undercut such an offer and thus the leader would end up funding no entrepreneurs. From this it follows that the leader cannot do better than to offer $R_{N M}=R_{v(B)}^{0}$. The optimal strategy for the follower is then to charge the very same interest rate from all the entrepreneurs, namely $R_{M, G}=R_{M, B}=R_{v(B)}^{0}$. This implies that $R_{v(B)}^{0}$ is quoted by both banks and to each entrepreneur category in equilibrium, and that $B$ is split between the two banks whereas the monitoring leader finances $G$. It follows that both banks earn 
zero expected profits from lending to $B$ while the monitoring bank earns positive profits from lending $G$. QED.

PROOF OF PROPOSITION 3 (Sketch). Details are omitted for brevity. The derivation of the Nash equilibrium loan rates is, however, standard, i.e., one first solves the follower's problem for any given interest of the leader and then utilizes the derived best response function when solving the leader's maximization problem. The equilibrium demands are found by computing the identity of the marginal type at the equilibrium interest rates. Given the equilibrium interest rates and demands, the expected profits are easily derived. They are for part (a)

$$
\begin{aligned}
& \pi\left(R_{H}, v(G B)\right)=\frac{1}{2}\left(1-\frac{v(G B)}{E(x)}\right) s^{m} \bar{\theta} \\
& \pi\left(R_{L}, v(G B)\right)=\left(\frac{1}{2}\right)^{2}\left(1-\frac{v(G B)}{E(x)}\right) s^{m} \bar{\theta}
\end{aligned}
$$

and for part (b):

$$
\begin{aligned}
& \pi\left(R_{H}, v(G B)\right)=\left(\frac{3}{4}\right)^{2}\left(1-\frac{v(G B)}{E(x)}\right) s^{m} \bar{\theta} \\
& \pi\left(R_{H}, v(G B)\right)=\left(\frac{1}{2}\right)^{3}\left(1-\frac{v(G B)}{E(x)}\right) s^{m} \bar{\theta}
\end{aligned}
$$

QED. 


\section{Appendix 2.}

In this appendix, we discuss the year-wise descriptive statistics and check them for any anomalies and/or outliers. In Table 1.1. we report mean, median, standard deviation, minimum and maximum value for each year and variable. All figures are in Finnish markka and in nominal terms.

The mean amount of loans extended was the lowest in 1992, and increased thereafter. The same applies for deposits. All four interest rates (loan, inter-bank loan, deposit, and inter-bank deposit) decrease every year. The mean loan interest rate goes from $12.03 \%$ in 1992 to $7.39 \%$ in 1996 . Our calculated cost of funds (INTD) decreases from $7.43 \%$ to $2.49 \%$. In line with this, the ratio of deposits from customer to total deposits $(R D E P)$ increases over time. In 1992, the mean of $R D E P$ is $82.56 \%$, and peaks in 1996 at $88.26 \%$. Interestingly, and contradicting industry figures, the default costs were at their lowest in 1992; the default costs of the whole banking industry peaked that year. At their highest (in 1994), the mean default costs were $1.77 \%$ of loans extended. This masks wide bank-level variation however. Each year, some banks report zero default costs. At the same time, the maximum default costs vary between $8.65 \%$ (in 1996) and $17.05 \%$ (in 1993) of loans extended.

During the observation period, banks were changing their branch networks, and adjusting the number of employees. The cooperative banks are generally held to have been the slowest to make such adjustments, and our numbers bear that out. The mean number of branches decreases from 3.6 in 1992 to 2.9 in 1996 , but increases first in between. Personnel costs are very stable, with the mean at around 5.5 Million FIM. Unsurprisingly therefore, personnel costs per branch exhibit an increasing trend. 
Checking the year-wise minima and maxima for each bank-level variable revealed no outliers in the sense that the year-to-year changes in these were roughly proportional to the changes in sample first moments. The only extreme value that changes markedly is that of INEFF: whereas the sample moments are stable, the maximum decreases from 3.09 in 1993 to 1.52 in 1994. Sample second moments of all bank-level variables are remarkably stable over the observation period, especially in light of the changing macroeconomic conditions.

Table 1.1

Yearly descriptive statistics of bank variables

\begin{tabular}{|c|c|c|c|c|c|}
\hline \multicolumn{6}{|c|}{ Deposits, 1000000 FIM } \\
\hline year & Mean & Med. & S.d. & Min. & Max. \\
\hline 1992 & 241.5775 & 123.641 & 384.2059 & 11.0846 & 2969.309 \\
\hline 1993 & 258.4518 & 131.3481 & 416.6836 & 12.6948 & 3244.395 \\
\hline 1994 & 314.6419 & 159.4877 & 524.9837 & 13.6927 & 4194.973 \\
\hline 1995 & 324.3661 & 162.7845 & 535.9779 & 13.8813 & 4226.674 \\
\hline 1996 & 328.7691 & 160.7896 & 544.3834 & 14.1277 & 4285.681 \\
\hline \multicolumn{6}{|c|}{ LOAN } \\
\hline year & Mean & Med. & S.d. & Min. & Max. \\
\hline 1992 & 242.4031 & 108.1146 & 439.4923 & 6.3583 & 3296.819 \\
\hline 1993 & 247.7302 & 111.2777 & 451.8151 & 7.0851 & 3358.258 \\
\hline 1994 & 275.5024 & 122.9388 & 515.3931 & 7.8430 & 3875.546 \\
\hline 1995 & 264.1695 & 119.7953 & 485.1355 & 7.7068 & 3734.778 \\
\hline 1996 & 262.5445 & 119.4842 & 481.9306 & 7.2394 & 3800.051 \\
\hline \multicolumn{6}{|c|}{ Deposit interest rate (from customers only) } \\
\hline year & Mean & Med. & S.d. & Min. & Max. \\
\hline 1992 & 0.070867 & 0.0707 & 0.004618 & 0.0565 & 0.0831 \\
\hline 1993 & 0.047007 & 0.0463 & 0.004034 & 0.0365 & 0.0611 \\
\hline 1994 & 0.028483 & 0.0284 & 0.002412 & 0.0225 & 0.0364 \\
\hline 1995 & 0.027876 & 0.0277 & 0.002588 & 0.0210 & 0.0377 \\
\hline 1996 & 0.020888 & 0.0207 & 0.001649 & 0.0178 & 0.0288 \\
\hline \multicolumn{6}{|c|}{ Loan interest rate (to customers only) } \\
\hline year & Mean & Med. & S.d. & Min. & Max. \\
\hline 1992 & 0.1203 & 0.1207 & 0.005476 & 0.1011 & 0.1344 \\
\hline 1993 & 0.0996 & 0.1004 & 0.007272 & 0.0558 & 0.1164 \\
\hline 1994 & 0.0853 & 0.0852 & 0.004791 & 0.0708 & 0.1059 \\
\hline 1995 & 0.0874 & 0.0873 & 0.004120 & 0.0742 & 0.1005 \\
\hline 1996 & 0.0739 & 0.0736 & 0.004211 & 0.0636 & 0.0990 \\
\hline \multicolumn{6}{|c|}{ Inter-bank lending interest rate } \\
\hline year & Mean & Med. & S.d. & Min. & Max. \\
\hline 1992 & 0.0818 & 0.0789 & 0.025919 & 0.0297 & 0.1333 \\
\hline 1993 & 0.0716 & 0.0721 & 0.018423 & 0.0254 & 0.1163 \\
\hline 1994 & 0.0581 & 0.0580 & 0.011537 & 0.0294 & 0.0912 \\
\hline 1995 & 0.0573 & 0.0571 & 0.011230 & 0.0319 & 0.0970 \\
\hline 1996 & 0.0559 & 0.0561 & 0.009925 & 0.0277 & 0.0885 \\
\hline
\end{tabular}

